4) In case of infusion of galactose solution blood glucose decreased parallel to the increasing value of the total blood hexose.

There was a similar patten of insulin-like activity and glucagon-like activity of blood as in the case of glucose infusion.

Thus, galactose seems to promote glucagon secretion, insulin consumption and subsequent insulin secretion. A-V ratio also showed increase on galactose infusion.

5) No paticular change of insulin-like activity or glucagon-like activity of blood was observed on levulose infusion. This seems to indicate that insulin is not necessarily required for metabolism of levulose.

Total hexose of blood showed no corresponding increase after levulose infusion. This seems to indicate the relatively quick break down of levulose after infusion. A-V ratio showed no increase on levulose infusion.

6) Electrical stimulation of Vagal Nerve brought about no regular increase or decrease of insulinlike activity of blood drawn from V. pancreaticoduodenalis sup.. In two dogs with relatively high insulin-like activity of blood in preexperimental stadium there occurred decreased insulin value but it was reversed in one dog with low initial blood insulin level.

Thus, attempt has been made to elucidate from this view-point, that stimulation of vagal nerve does not exert a direct accelerating effect on $\beta$-cell of islets, it influences blood insulin through complex metabolic and nervous routes.

No apparent difference between the right or the left vagal stimulation was observed. Blood glucagon-like activity and $\mathrm{A}-\mathrm{V}$ ratio showed no particular change after vagal stimulation.

7) Dogs, which received right as well as left vagal section, showed decreased response of blood insulin level on glucose infusion in comparison to normal dogs.

Glucagon-like activity of blood showed decrease in the same instance. This phenemenon was explained from the plausible consumption of glucagon on glucose infusion.

\title{
Experimental Studies on the Correlation Between Male Hormones and Pituitary-thyroid System.
}

\author{
Report I. Influence of castration and male hormone administration \\ upon the plasma TSH-level and serum PBI.
}

\section{Noriyuki YONEZAWA}

The 2nd Department of Internal Medicine, Kobe Medical College, Kobe, Japan.

(Director : Prof. Dr. Shozo Tsuji)

The correlation between female gonads and pituitary-thyroid system has been discussed very often in the realm of endocrinology and gynecology. As regard to the influence of male gonads upon pituitary-thyroid system there are still many discrepancies of opinion about the result of experimental studies. One of the reasons of such diverse opinions consists in the lack of an appropriate method 
for the direct measurement of thyrotropin (hereafter abbrev. as TSH) activity in blood. Ogura et al. of our clinic developed a new method for the direct measurement of plasma TSH activity using $\mathrm{I}^{131}$-release method of calf thyroid slices with Warburg apparatus.

The author therefore tried to study the influence of castration and male hormone administration, i.e., testosterone propionate (abbrev. as T.P.) and Methylandrostendiol (abbrev. as MAD) upon the plasma TSH activity of normal and thyroidectomized dogs with Ogura's method. The serum PBI level was also determined on normal and castrated dogs, further more on castrated dogs treated with T.P. successively using Barker's method.

The results are summarized as follows :

1) The castrated male adult dogs showed a transient elevation of plasma-TSH activity up to the 9th day after castration. A rather sharp decrease of plasma-TSH activity was observed thereafter, reaching it's lowest limit in postoperative 30 60days. The plasma-TSH level then turned to increase but it remained still in subnormal level even 120 days after castration.

2) The plasma-TSH level of thyroidectomized dogs showed marked increase after the operation. If these thyroidectomized dogs are castrated, the elevated plasma-TSH volue turns directly to decrease, showing no transient increase, which was observed on nonthyroidectomized dogs. The plasma-TSH value reached the lowest level in between 8 14 days after castration, then it began to increase gradually but even 100 days after castration it remained still in a lower level than preoperative niveau.

3) Injection of T.P. to the male castrated dogs produced elevation of plasma-TSH value. Simultaneous observation of serum PBI showed also an elevated value. The most marked increase of plasma-TSH was observed with single injection of testostererone heptanoate in doses of $5.0 \mathrm{mg} / \mathrm{kg}$ of body weight, then T.P. $1.0 \mathrm{mg} / \mathrm{kg} /$ day and $0.5 \mathrm{mg} / \mathrm{kg} /$ day for three successive days followed the former. Single injection of T.P. in doses of $1.0 \mathrm{mg} / \mathrm{kg}, 5.0 \mathrm{mg} / \mathrm{kg}$ and $0.1 \mathrm{mg} / \mathrm{kg}$ brought about also a slight increase of plasma-TSH value in order.

4) The castrated dogs responded with greater percent inerease of plasma-TSH upon the injection of T.P. as compared with the castrated-thyroidectomized dogs. A Plausible explanation of this phenomenon was sought in the lowered reactivity of elevated plasma-TSH of the thyroidectomized dogs.

5) The decrease of plasma-TSH value on the castrated dogs and the increase of the value upon injection of T.P. are most plausibly explained from the antagonism of TSH-producing activity and gonadotropin-producing activity of anterior pituitary.

6) Injection of MAD showed no apparent influence upon the plasma-TSH level of male castrated dogs and castrated-thyroidectomized dogs. MAD seems to have no effect upon pituitary-thyroid system.

\section{Report II. On the functional response of thyroid upon castration and male hormone administration}

Following the report I, the behavior of thyroid gland under castration or male hormone administration was observed. Normal and castrated adult male dogs under thyroid-constant feeding were used in the following experiment to observe the behavior of the thyroid gland. The thyroid gland was totally resected under Isozol-anesthesia and the following examinations were carried out on them.

1) Papar radiochromatography of the iodinized amino acid fractions of the thyroid gland.

The gland was homogenized with $\mathrm{NH}_{4} \mathrm{OH}-\mathrm{NH}_{4} \mathrm{Gl}$ buffer, then digested with trypsin and urea: The butanol extract of trypsin digest was examined on paper-radiochromatography.

2) Percent uptake of $\mathrm{I}^{131}$ after Leblond \& Gross and Soliman \& Reineke's method.

Vol. 37 No. 6 
3) $\mathrm{PBI}^{131}$ conversion ratio, i.e.

$$
\frac{\text { the total organic } \mathrm{I}^{131} \text { serum }}{\text { the total serum } \mathrm{I}^{131}} \text { ratio }
$$

4) PBI of the serum according to Barker's Method.

5) Histological classification of the thyroid with special reference to the functional behavior of thyroid after Irie's classification.

The results of the observation are summarized as follows :

1) Paper radiochromatographic fractionating of $\mathrm{I}^{131}$-labeled amino acid fractions of the thyroid gland digest resected from the castrated dogs (300 360 days after castration) showed no abnormal pattern as compared with that of normal thyroid.

2) Injection of testosterone propionate to the castrated dogs produced decrease of MIT-DIT fraction and increase of $T_{3}-T_{4}$ fraction on the paper radiochromatography, consequently the ratio $T_{3}+T_{4} /$ MIT + DIT showed increase.

3) Injection of thyrotropin (Pretiron, Schering) to the castrated dogs brought about also decrease of MIT-DIT fraction and increase of $\mathrm{T}_{3}-\mathrm{T}_{4}$ fraction with consequent increase of $\mathrm{T}_{3}+\mathrm{T}_{4} / \mathrm{MIT}+\mathrm{DIT}$ ratio. Thus the pattern of ionized amino acid fractions of the thyroid gland showed the same response on the injection of testosterone propionate and thyrotropin. This result makes it plausible, that testosterone propionate exerts it's effect via stimulation of thyrotropin secretion.

4) Methylandrostendiol showed no apparent influence upon the distribution of $\mathrm{I}^{131}$-labeled amino acid compound of thyroid.

5) Parallel examinations of various functional criteria of the thyroid gland such as percent uptake of $\mathrm{I}^{131}$, serum $\mathrm{PBI}^{131}$ /serum tototal $\mathrm{I}^{131}$ ratio, serum $\mathrm{PBI}$ and histological classification of the thyroid showed evidence corresponding to the results mentioned in 2) to 4), i.e, the evidences corresponding to the hyperfunction of thyroid gland in the hormone production, where the increase of $\mathrm{T}_{3}+\mathrm{T}_{4}$ fractions and the derease of MIT + DIT fractions was observed on paper-raciochromatography.

\section{Studies on Diabetic $\beta_{1}$-Lipoprotein}

\section{Shigeo AKITA}

The 1st Department of Internal Medicine, Kyoto Prefectural University of Medicinc. (Directer : Prof. Hideo Yoshida)

We prepared $\beta_{1}$-lipoprotein from human diabetic serum and studied its diabetogenic action. The Following results were obtained.

1) Intravenously injected insulin $I^{131}$ was retained in the blood of diabetic patients with and without insulin treatment.

Therefore, it was suggested that diabetics had common unknown extracellular factors in their serum which impeded the distribution of insulin $\mathrm{I}^{131}$ to the tissue. At the same time, the blood sugar reduction by insulin was lower in diabetics than in normals.

2) Diabetic $\beta_{1}$-lipoprotein inhibited the glucose output of rat liver-slices and the glucose uptake of rat diaphragms, but in normal ones it accelerated both.

3) Diabetic $\beta_{1}$-lipoprotein inhibited the binding of insulin $I^{131}$ to liver, kidney and muscle slices

Vol. 37 No. 6 


\title{
男性ホルモンと下垂体甲状腺系との 相関に関する実験的研究
}

\author{
神戸医科大学第二内科学教室 (指導 辻 昇三教授) \\ 研究科学生 米澤 典 之
}

（昭和35年11月28日受付）

第 1 編 下垂体甲状腺刺激ホルモンとの相関について

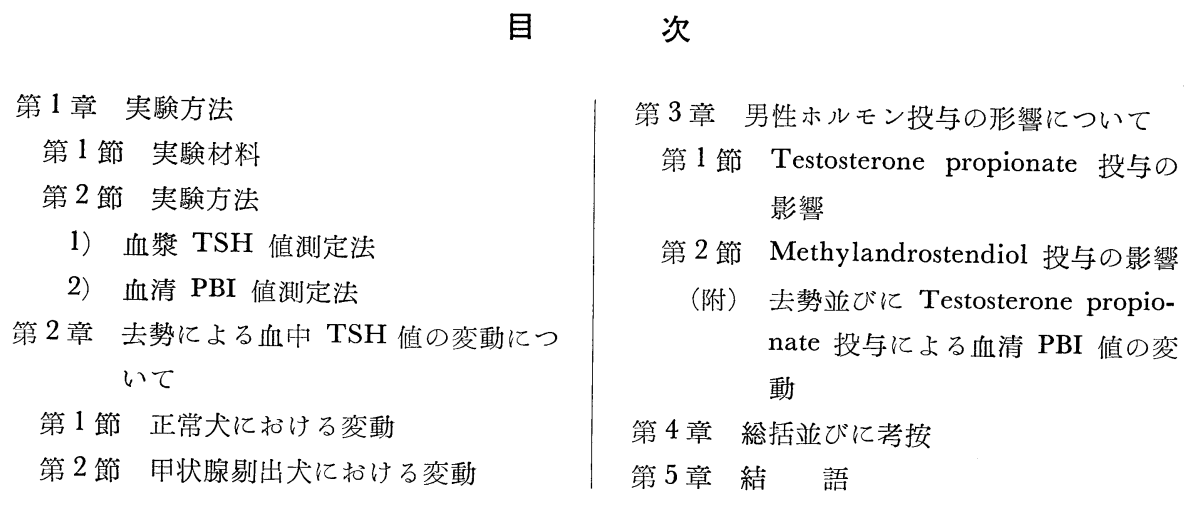

いとぐち

臨床的に甲状腺垸患に罹患する男女の差は圧倒的に女子に多く，例えばバセドウ氏病は女子が男子の 4 8 倍, 粘液水腫では 7 倍と何れも女子に多いてとが認められている. 従つて女性ホルモンの甲状腺に及ぼす 影響については古くから多くの研究がなされていて，その作用機序についても詳細な発表をみるととが出来 る.乙れに比して男性ホルモンの甲状腺への作用についての報告は少なく, 未だ定説がない. 更にてれが下 垂体甲状腺刺激ホルモン（TSH） に及ぼす影響については，その報告はきわめて少なく，特に血中 TSH 值に与える影響についての報告には未だ接しない，乙れは血中 TSH が微量であるために，その測定が極め て困難であつたてとによる. 教室の小倉 ${ }^{1}$ はさきに，in vitro における新鮮な牛甲状腺薄片 $I^{131}$ Release 法 を発案して血中 TSH の定量を可能ならしめた．著者はての方法を用いて，種々なる条件の下て雄犬に男性 ホルモンを投与し，その血中 TSH レベルの変動を観察してその結果を先ず本編て於て報告する. 第 2 編で は，乙れらの実験犬を用いて，男性ホルモン投与時の甲状腺を種々観察し，第一編と併せて男性ホルモンの 下垂体甲状腺系に及ぼす作用機序の総括的な考察を行なつた。

\section{第 1 章 実 験 方 法}

\section{第 1 節 実験材料}

実験動物には全て生後 $1 \sim 3$ 年を経た体重 $10 \sim 15 \mathrm{~kg}$ の健康は成熟雄雑種犬を使用した. 実験犬は常に一定 の条件で飼育する様に留意し，特に飼料はキャベッ，海藻類等の甲状腺機能に影響をあたえるものをさけた。 測定は酷暑悠寒時をさけて行ない，常に同一条件で飼育した対照犬を用いて観察した。 
第 2 節 実験方法

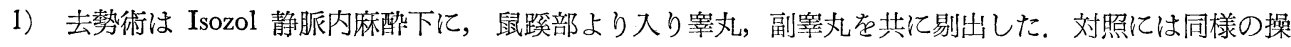
作で入り，白膜に切開を加えたのみで手術を終えた偽手術犬を用いた。なお夙所消毒剂にはヨードチンキの 使用を避けた。

2）甲状腺剔出術は同様静脈内麻酔下に，上皮小体を残して出来るだけ全剔出を行ない，術後血清 PBI の減少を確認した

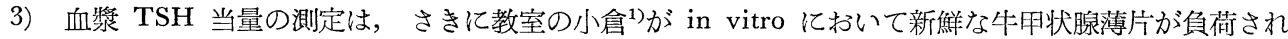
た $\mathrm{I}^{131}$ を放出する際に，そのメヂウムに含まれる TSH の濃度に一定の相関を以て ${ }^{131}$ の放出が抑制される ことを利用して発案した牛甲状腺薄片 $I^{131}$ Release 法によつた. TSH の測定の Standard には， Schering社

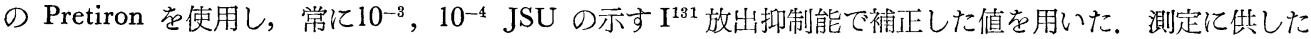
血液は全て頸静脈より Heparin 加採血によつた。

4) 血清 PBI の測定は, Barker²)のアルカリ灰化法によつて行なつた.

\section{第 2 章 去勢による血中 TSH 值の変動について}

\section{第 1 節 正常犬における変動}

第1図去勢による血中 TSH 值の経時的変動

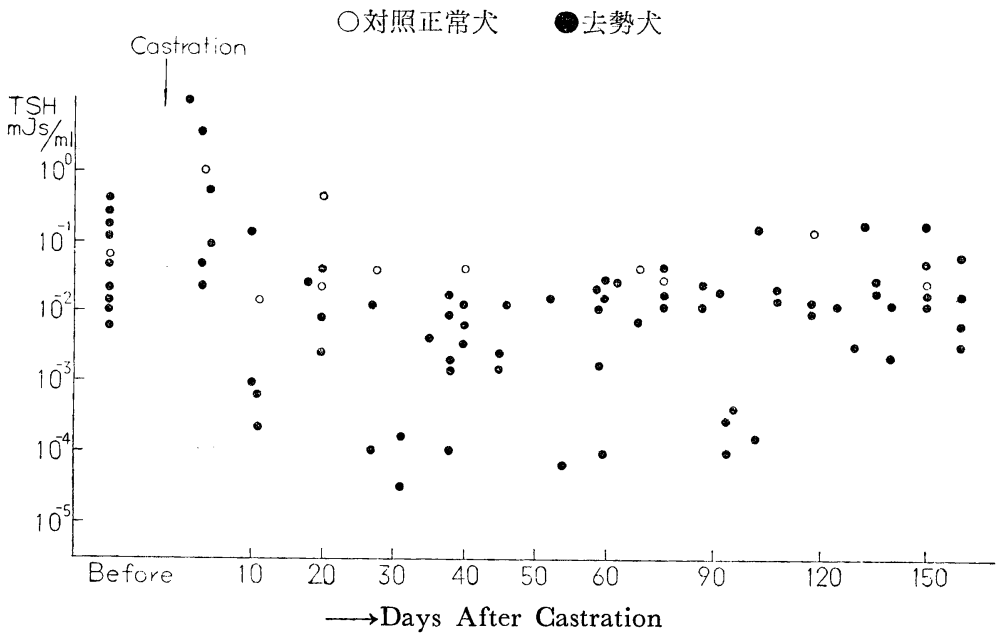

男性ホルモンの下垂体甲状腺系に及ぼす影 響をみるに先だつて，正常犬においては去勢 により血中 TSH レベルが如何に変動するか を観察した。第 1 図を去勢犬 9 例（内 1 例死 亡）の血獎 TSH 值の変動を経時的に測定し た値を示し，第 2 図はその平均值を示した。 すなわち図の如く術後 9 日以内においては， その TSH が一時増加する傾向を示した．次 で減少の傾向をたどり，30日以降60日の間に おいては最低值に減少した。しかる後漸時増 加の傾向をたどつて行くが，術後 120 日に至 つてもその值は術前に比して低く，術前值の
第 2 図去勢による血中 TSH 值の経時的変動 対照正常犬 去勢犬

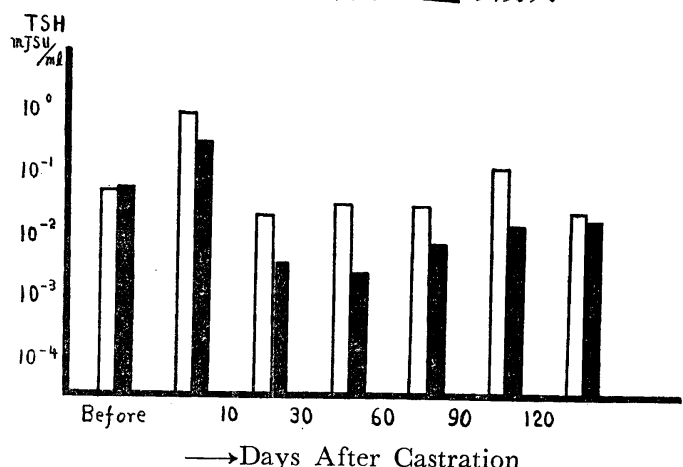


約 $40 \%$ に止つている. 対照の㑇手術例は同期間中，術後 9 日以内において一時増加した以後は術前値に比し て有意差のある傾向を示さなかつた。

\section{第 2 節 甲状腺剔出犬における变動}

前節においては正常犬が去勢による血中 TSH 值の隇少を来すととを認めた。他方，甲状腺機能に及ぼす TSH の影響については，古くからその主従性について種々論議されている処である。すすなおち TSH の刺 激によつて甲状腺ホルモン分泌が促進されるとする下垂体主説と，血中甲状腺ホルモンの低下によつて下垂 体前葉の TSH 分泌が促進されるとする下垂体従説とがある。一般には, 甲状腺の自律性を強調する後者の 所謂 feed back 説が有力である. 著者はこの feed back の影響の関与を除外する為に，あらかじめ甲状腺 を剔出した犬を用いて，去勢による血中 TSH 值の变動を観察した，乙てに注意すべきは，甲状腺剔出が

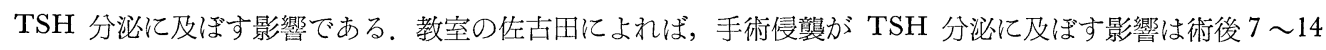

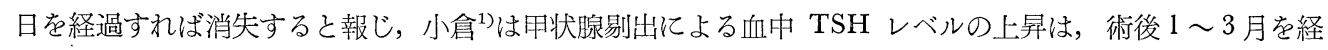
過すればほぼ一定のレベルに固定するととを認めている。乙の為に甲状腺剔出術後 3 力月以後において去勢 を行なつて観察した，第 3 図はその経時的変動を示し，第 4 図は同期閒中の平均值を表す。すなわち甲状腺

第3 図用状腺剔出犬の去勢による血中 TSH 值の変動

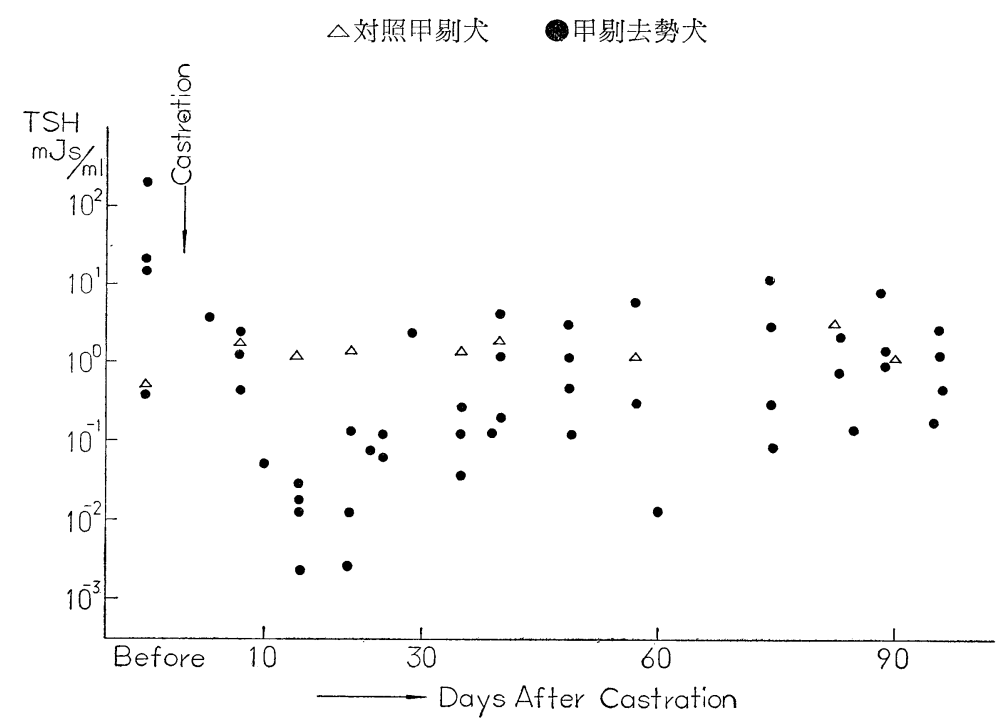

第4 図 甲状腺剔出犬の去勢飞.上る血中 TSH 值の変動

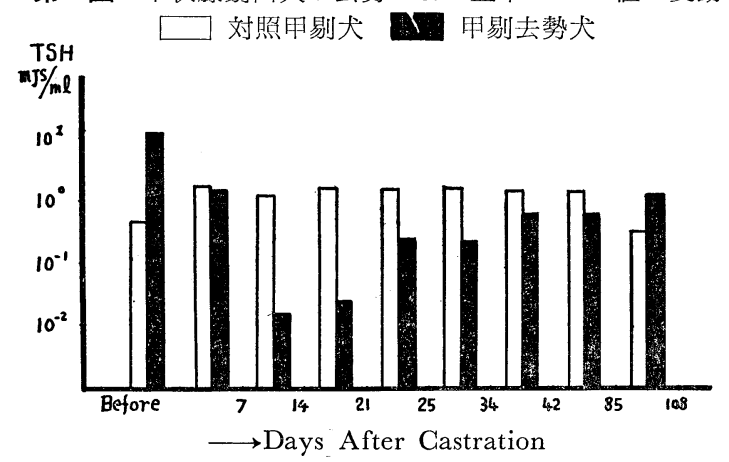

剔出犬の血中 TSH 值は去勢術前において 正常犬の10〜20倍の高値を示している. 去 勢を行なうと，正常犬に去勢を行なつた場 合と異なり，手術後直ちに血中 TSH 值は 減少して $8 \sim 14$ 日後に最低值を示した. 次 で渐時上昇の傾向をたどるが，術後 100 日 前後においても尚術前值に比して低值を示 しその10\%程度に止つた. 対照とした非去 勢甲状腺剔出犬においては, 同期間中有意 の変動の傾向を示さなかつた。すなわち甲 状腺剔出犬においても, 正常犬と同様去勢 
により血中 TSH 值の減少を認めた.

\section{第 3 章 男性ホルモン投与の影響について}

\section{第 1 節 Testosterone propionate 投与の影響}

男性ホルモンとしては, Androsterone, Dehydroandrosterone, Testosterone, Methyltestosterone, Methylandrostendiol 等があるが, Testosterone, Methyltestosterone は男性化作用が強く, Methylandrostendiol は蛋白同化作用が著明で男性化作用は弱いと されている。著者は第 2 章において，正常犬並びに甲 状腺剔出犬が去勢により血中 TSH 值の低下を示すて とを認めたが，本章においては，乙れらの去勢犬に男 性ホルモンを投与して血中 TSH 值の変動を観察し た。

先ず男性ホルモンとして Testosterone propionate

（以下T.P.と称す）を選び，その結晶水性䯚濁液を筋 肉内に投与して観察を行なつた，対照には，該実験犬 に投与したと同容量の生理食塩水を筋肉内に投与した 正常大及び甲状腺剔出犬（以下甲剔犬之称す）を用い た. 実験中，単回投与時では絶食せしめ，連続投与時 は常に一定の食慨で飼育した，以下投与前のの血中值 の平均值を 1.0 として表し, 投与後の血中 TSH 值の 平均を比で示した。

\section{1) T.P. $0.1 \mathrm{mg} / \mathrm{kg}$ 単回投与}

正常犬を去勢した実験群（以下去勢群と称す）にお いては表 1）に示す如く投与前血中 TSH 值1.0亿比し て，6時間後に血中 $\mathrm{TSH}$ 值は7.50 と增加を示してい

第 1 表 去勢犬に対する Testosterone Prop. 投与の影響（T.P.単回投与）

\begin{tabular}{|c|c|c|c|c|c|}
\hline \multirow{2}{*}{ 处 置 } & \multirow{2}{*}{\multicolumn{2}{|c|}{ T.P.投与量 }} & \multirow{2}{*}{ 審験 } & \multicolumn{2}{|c|}{ 血漿 TSH 值 $\mathrm{mJSU} / \mathrm{ml}$} \\
\hline & & & & 投与前 & 投与後 \\
\hline \multirow{4}{*}{ 去勢群 } & \multirow{4}{*}{\multicolumn{2}{|c|}{$0.1 \mathrm{mg} / \mathrm{kg}$}} & 1 & 0.005 & 0.004 \\
\hline & & & 2 & 0.006 & 0.100 \\
\hline & & & 3 & 0.008 & 0.012 \\
\hline & & & 4 & 0.006 & 0.063 \\
\hline \multirow{2}{*}{$\begin{array}{l}\text { 平 } \\
\text { 增 }\end{array}$} & \multicolumn{3}{|c|}{ 均 } & 0.006 & 0.045 \\
\hline & \multicolumn{3}{|c|}{ 加 } & 1.00 & 7.50 \\
\hline \multirow{4}{*}{$\begin{array}{l}\text { 甲剔- } \\
\text { 去勢群 }\end{array}$} & \multirow{4}{*}{\multicolumn{2}{|c|}{$0.1 \mathrm{mg} / \mathrm{kg}$}} & 5 & 0.288 & 0.809 \\
\hline & & & 6 & 0.832 & 0.100 \\
\hline & & & 7 & 2.040 & 6.520 \\
\hline & & & 8 & 0.219 & 0.380 \\
\hline \multirow{2}{*}{$\begin{array}{l}\text { 平 } \\
\text { 増 }\end{array}$} & \multirow{2}{*}{\multicolumn{3}{|c|}{$\begin{array}{l}\text { 均 } \\
\text { 率 }\end{array}$}} & 0.845 & 1.955 \\
\hline & & & & 1.00 & 2.20 \\
\hline \multirow{2}{*}{$\begin{array}{l}\text { 正常犬 } \\
\text { 甲剔犬 }\end{array}$} & \multirow{2}{*}{\multicolumn{2}{|c|}{ 対＼cjkstart照 }} & 9 & 0.617 & 0.511 \\
\hline & & & 10 & 1.620 & 1.060 \\
\hline
\end{tabular}

第 2 表 去勢犬に対する Testosterone Prop. 投与の影響（T.P.単回投与）

\begin{tabular}{|c|c|c|c|c|c|c|}
\hline \multirow{2}{*}{ 処 置 } & \multirow{2}{*}{ T.P.投与量 } & \multirow{2}{*}{ 実験番号 } & \multicolumn{4}{|c|}{ 血漿 $\mathrm{TSH}$ 值 $\mathrm{mJSU} / \mathrm{ml}$} \\
\hline & & & 前 值 & 6 時間後 & 12 時間後 & 24 時間後 \\
\hline \multirow{2}{*}{ 去勢群 } & \multirow{2}{*}{$1.0 \mathrm{mg} / \mathrm{kg}$} & 1 & 0.002 & 0.479 & 0.490 & 0.003 \\
\hline & & 2 & 0.034 & 0.204 & 0.288 & 0.013 \\
\hline \multicolumn{3}{|c|}{ 平 } & 0.018 & 0.341 & 0.389 & $0 \cdot 008$ \\
\hline \multicolumn{3}{|c|}{ 増 加 率 } & 1.000 & 19.0 & 21.6 & 0.44 \\
\hline \multirow{3}{*}{$\begin{array}{l}\text { 甲剔- } \\
\text { 去勢群 }\end{array}$} & \multirow{3}{*}{$1.0 \mathrm{mg} / \mathrm{kg}$} & 3 & 8.320 & 15.60 & 20.20 & 6.790 \\
\hline & & 4 & 0.202 & 4.170 & 0.204 & 0.263 \\
\hline & & 5 & 0.155 & 0.912 & 6.610 & 0.091 \\
\hline \multirow{2}{*}{\multicolumn{3}{|c|}{$\begin{array}{l}\text { 平 均 } \\
\text { 増 加 率 }\end{array}$}} & 4.318 & 10.34 & 13.50 & 3.557 \\
\hline & & & 1.00 & 2.40 & 3.13 & 0.82 \\
\hline \multirow{2}{*}{$\begin{array}{l}\text { 正常犬 } \\
\text { 甲剔犬 }\end{array}$} & \multirow{2}{*}{ 対 照 } & 6 & 0.036 & 0.043 & 0.039 & 0.025 \\
\hline & & 7 & 9.770 & 5.010 & 7.820 & 4.680 \\
\hline
\end{tabular}


る.甲剔犬を去勢した実験群（以下甲剔去勢群と称す）においては前値1.0亿対して 2.20 と増加しているが， その増加率は去勢群に較べて軽度であつた。

\section{2) T.P. $1.0 \mathrm{mg} / \mathrm{kg}$ 単回投与}

去勢群においては，第 2 表に示す如く前值1.0亿比し，6時間後は19.0, 12時間後は $21.6,24$ 時間後は0.44 となり, 投与後 6 ～12時間において著明なる增加を示し， 24時間後にはかえつて低くなつている. 甲剔去勢 群においては， 6 時間後は $2.40 ， 12$ 時間後は $3.13 ， 24$ 時間後においては 0.82 と去勢群同様に $6 \sim 12$ 時間後に おいて増加を示すが，その増加率は去勢群に比して軽微であり，24時間後ではほぼ前値に復している.

\section{3) T.P. $5.0 \mathrm{mg} / \mathrm{kg}$ 単回投与}

去勢群においては，第 3 表に示す如く前値1.0亿比し，6時間後は9.00, 12時間後は7.82, 24時間後は2.03 であり，同じく6〜12時間後において增加を示している．しかしその増加率はT.P. $1.0 \mathrm{mg} / \mathrm{kg}$ 単回投与に 比して少なく, 且つ24時間後においても効果の遷延を認めるてとが出来る. 甲剔去勢群においては前値は高 く，6時間後 $9.00 ， 12$ 時間後は3.61，24時間後は1.26とやはり $6 〜 12$ 時間後において増加を示しているが，

第 3 表 去勢犬に対する Testosterone Prop. 投与の影響（T.P.単回投与）

\begin{tabular}{|c|c|c|c|c|c|c|}
\hline \multirow{2}{*}{ 処 置 } & \multirow{2}{*}{ T.P.投与量 } & \multirow{2}{*}{ 実験番号 } & \multicolumn{4}{|c|}{ 血漿 TSH 值 $\mathrm{mJSU} / \mathrm{ml}$} \\
\hline & & & 前 值 & 6 時間後 & 12 時間後 & 24 時間後 \\
\hline \multirow{3}{*}{ 去勢群 } & \multirow{3}{*}{$5.0 \mathrm{mg} / \mathrm{kg}$} & 1 & 0.010 & 0.009 & 0.263 & 0.006 \\
\hline & & 2 & 0.012 & 0.085 & 0.224 & 0.007 \\
\hline & & 3 & 0.096 & 0.955 & 0.427 & 0.224 \\
\hline \multicolumn{3}{|c|}{ 平 } & 0.039 & 0.350 & 0.305 & 0.079 \\
\hline \multicolumn{3}{|c|}{ 増 加 率 } & 1.00 & 9.00 & 7.82 & 2.03 \\
\hline \multirow{3}{*}{$\begin{array}{l}\text { 甲剔- } \\
\text { 去勢群 }\end{array}$} & \multirow{3}{*}{$5.0 \mathrm{mg} / \mathrm{kg}$} & 4 & 0.151 & 6.760 & 1.350 & 0.955 \\
\hline & & 5 & 0.186 & 0.630 & 0.316 & 0.135 \\
\hline & & 6 & 0.692 & 1.910 & 2.040 & 0.209 \\
\hline & \multirow{2}{*}{\multicolumn{2}{|c|}{$\begin{array}{ll}\text { 平 均 } \\
\text { 増 加 率 }\end{array}$}} & 0.343 & 3.091 & 1.235 & 0.433 \\
\hline & & & 1.00 & 9.00 & 3.61 & 1.26 \\
\hline \multirow{2}{*}{$\begin{array}{l}\text { 正常犬 } \\
\text { 甲剔犬 }\end{array}$} & \multirow{2}{*}{ 対 照 } & 7 & 0.178 & 0.164 & 0.158 & 0.129 \\
\hline & & 8 & 2.140 & 2.250 & 3.020 & 4.680 \\
\hline
\end{tabular}

第 4 表 去勢犬に対する Testosterone Prop. 投与の影響 (T.P. $0.5 \mathrm{mg} / \mathrm{kg} /$ day 3 日間連続投与)

\begin{tabular}{|c|c|c|c|c|}
\hline \multirow{2}{*}{ 処 置 } & \multirow{2}{*}{$\begin{array}{l}\text { 実験 } \\
\text { 番号 }\end{array}$} & \multicolumn{3}{|c|}{ 血漿 $\mathrm{TSH}$ 值 $\mathrm{mJSU} / \mathrm{ml}$} \\
\hline & & 前 值 & 3 日後 & $\begin{array}{l}\text { 投与中止 } \\
\text { 後7日 }\end{array}$ \\
\hline \multirow{4}{*}{$\begin{array}{c}\text { 正常群 } \\
+\stackrel{+}{\text { T.P. }}\end{array}$} & 1 & 0.081 & 1.700 & 0.083 \\
\hline & 2 & 0.045 & 0.057 & 0.089 \\
\hline & 3 & 0.089 & 0.015 & - \\
\hline & 4 & 0.646 & 1.820 & - \\
\hline 平 & 均 & 0.215 & 0.896 & - \\
\hline 增 加 & 率 & 1.00 & 4.17 & - \\
\hline
\end{tabular}

\begin{tabular}{l|r|l|l|c}
\hline & 5 & 0.001 & 0.024 & 0.023 \\
& 6 & 0.004 & 0.118 & - \\
& 7 & 0.004 & 0.012 & 0.031 \\
去勢群 & 8 & 0.005 & 0.380 & - \\
T.P. & 9 & 0.123 & 0.547 & 0.158 \\
& 10 & 0.013 & 3.390 & - \\
& 11 & 0.002 & 3.020 & 0.003 \\
& 12 & 0.003 & 1.000 & - \\
\hline 平 & 13 & 0.011 & 0.229 & 0.007 \\
增 加 & 率 & 1.00 & 42.0 & 1.93 \\
\hline
\end{tabular}


その程度は去勢群とほぼ同様で，24時間後には殆んど前值に復している。

\section{4) T.P. $0.5 \mathrm{mg} / \mathrm{kg} / \mathrm{day} 3$ 日間連続投与}

最終投与の 6 時間後に採血を行なつて 前值して比較すれば，第 4 表に示す如く正常群においては，前值 1.0 亿比して 3 日後で 4.17 ，去勢群も 3 日後は 42.0 といずれも増加を示している．乙の場合，去勢群では正 常群に較べて増加は著明で約10倍の効果を示している。な抢去勢群の約半数例につき投与中止後 7 日目に血 中 TSH 值を検して，その平均值がほぼ前值に復しているととを認めた。

\section{5) T.P. $1.0 \mathrm{mg} / \mathrm{kg} / \mathrm{day} 3$ 日間連続投与}

前項と同じく最終投与の 6 時間後において測定して投与前佔に比校すれば第 5 表に示す如く去勢群では前 値1.0亿対して 3 日後には 85.0 と著明な增加を示し，投与中止後 7 日目はおいては 1.5 とほぼ前値に近い值に 復していた。.甲剔去勢群においては， 3 日後 67.0 と著明に增加し，投与中止後 7 日目においては 0.58 と前值 の約半分の值を示している.

\section{6) Testosterone heptanoate $5.0 \mathrm{mg} / \mathrm{kg}$ 単回投与}

Testosterone の誘導体である Testosterone heptanoate（邦品 Enalmon-Depot）は持続性効果を有する てれを去勢犬に投与した場合第 6 表に示す如く前值1.0亿対して，3 日後では101 と著明に増加を示し，17日 後においても 8.50 となお高值を続けているてとを認めた。

第 5 表 去勢犬に対守る Testosterone Prop. 投与の影響 (T.P. $1.0 \mathrm{mg} / \mathrm{kg} /$ day 3 日間連続投与)

\begin{tabular}{|c|c|c|c|c|}
\hline \multirow{2}{*}{ 処 置 } & \multirow{2}{*}{$\begin{array}{l}\text { 実験 } \\
\text { 番号 }\end{array}$} & \multicolumn{3}{|c|}{ 血漿 $\mathrm{TSH}$ 值 $\mathrm{mJSU} / \mathrm{ml}$} \\
\hline & & 前 值 & 3 日後 & $\begin{array}{l}\text { 投与中止 } \\
\text { 後 } 7 \text { 日 }\end{array}$ \\
\hline 去勢群 & 1 & 0.004 & 0.269 & 0.007 \\
\hline T.P. & 2 & 0.004 & 0.417 & 0.004 \\
\hline \multirow{2}{*}{$\begin{array}{l}\text { 平 } \\
\text { 增 加 }\end{array}$} & 均 & 0.004 & 0.343 & 0.006 \\
\hline & 率 & 1.00 & 85.1 & 1.50 \\
\hline \multirow{4}{*}{$\begin{array}{c}\text { 甲剔- } \\
\text { 去勢群 } \\
+\stackrel{+}{+} \\
\text { T.P. }\end{array}$} & 3 & 0.044 & 0.191 & 0.029 \\
\hline & 4 & 0.042 & 0.309 & 0.044 \\
\hline & 5 & 0.654 & 6.610 & 0.086 \\
\hline & 6 & 0.891 & 3.890 & 0.814 \\
\hline \multirow{2}{*}{$\begin{array}{l}\text { 平 } \\
\text { 増 加 }\end{array}$} & 均 & 0.408 & 2.747 & 0.235 \\
\hline & 率 & 1.00 & 67.5 & 0.583 \\
\hline \multirow{2}{*}{$\begin{array}{l}\text { 正常犬 } \\
\text { 甲剔犬 }\end{array}$} & $\begin{array}{c}7 \\
\text { (対昭) }\end{array}$ & 0.171 & 0.174 & 0.383 \\
\hline & S & 0.589 & 0.400 & 0.293 \\
\hline
\end{tabular}

第 6 表 去勢犬に対する Testosterone heptanoate 投与の影響 (Test. hept. $5.0 \mathrm{mg} / \mathrm{kg}$ 筋 肉内単回投与)

\begin{tabular}{|c|c|c|c|c|c|}
\hline \multirow{2}{*}{ 処 置 } & \multirow{2}{*}{$\begin{array}{l}\text { 実験 } \\
\text { 番号 }\end{array}$} & \multicolumn{4}{|c|}{ 血漿 $\mathrm{TSH}$ 值 $\mathrm{m} J \mathrm{SU} / \mathrm{ml}$} \\
\hline & & 前 值 & 3 日後 & 17日後 & 21 日後 \\
\hline \multirow{6}{*}{$\begin{array}{l}\text { 去 勢 群 } \\
\quad+ \\
\text { Test. hept. }\end{array}$} & 1 & 0.026 & 0.105 & 0.038 & 0.028 \\
\hline & 2 & 0.009 & 0.398 & 0.003 & 0.016 \\
\hline & 3 & 0.021 & 0.002 & 0.001 & - \\
\hline & 4 & 0.007 & 4.230 & 0.468 & - \\
\hline & 5 & 0.005 & 2.450 & 0.001 & - \\
\hline & 6 & 0.005 & 0.151 & - & - \\
\hline \multicolumn{2}{|c|}{ 平均 } & 0.012 & 1.223 & 0.102 & - \\
\hline \multicolumn{2}{|c|}{ 增加 率 } & 1.00 & 101 & 8.50 & - \\
\hline 正 常 犬 & $\begin{array}{c}7 \\
\text { 対照 }\end{array}$ & 0.147 & 0.114 & 0.178 & - \\
\hline
\end{tabular}

以上，去勢群並びに甲剔去勢群に T.P.を種々の量， 方法によつて投与し血中 TSH 值の変動を観察した が，その何れの場合においても血中 TSH 值の增加が

認められた．且つその増加の程度は，一般に去勢群が甲剔去勢群よりも著明であつた。乙れは甲剔去勢群の 血中 TSH レベルが去勢群に比して既に高く，重なる TSH 分泌刺激に応ずる Space が少ない為ではない かと考えられる. 又去勢群に於ては血中 TSH 値は低值を示し，從つてT.P.に対する反応として増量を示す 場合にも，正常域まで恢復した時には増加率としては異常に高い値を示しうるてとも去勢群での増加群の高 い原因となつている．投与の方法としては Test. hept. $5.0 \mathrm{mg} / \mathrm{kg}$ 単回投与の 3 日後における血中 TSH 值の 増加率が最も著明で, T.P. $1.0 \mathrm{mg} / \mathrm{kg} /$ day 3 日間連続投与がてれに次ぎ，以下 $0.5 \mathrm{mg} / \mathrm{kg} / \mathrm{d}$ day 3 日間連続投 与, $1.0 \mathrm{mg} / \mathrm{kg}$ 単回投与, $5.0 \mathrm{mg} / \mathrm{kg}$ 単回投与, $0.1 \mathrm{mg} / \mathrm{kg}$ 単回投与の順に効果を示している.すなわち, 投与方法としては連続投与，投与量としては $1.0 \mathrm{mg} / \mathrm{kg} / \mathrm{day}$ の場合が最も安定した TSH 分泌充進の効果を 
示す様である．対照犬においては，正常犬，甲剔犬を通じて血中 TSH 值の変動は僅少で，且つ一定の傾向 を認めなかつた。

\section{第 2 節 Methylandrostendiol 投与の影響}

Methylandrostendiol（以下 MAD と称す）は男性ホルモン中蛋白同化作用が著明で，逆に男性化作用は 弱いとされている，本節においては MAD の水性懸濁液を筋肉内に投与してその血中 TSH 值に及ばす影 響を観察した，対照犬には同容量の生理食塩水を筋肉内投与して実験した.

\section{1) MAD $1.0 \mathrm{mg} / \mathrm{kg}$ 単回投与}

第 7 表に示す如く，去勢群においては，前值を 1.0 として較べると 6 時間後は $0.69 ， 12$ 時間後は $0.73 ， 24$ 時間後は 1.1 と 6 12時間後において僅かに減少し，24時間後では前值は復している. 甲剔去勢群において は，6時間後は0.25，12時間後は0.10，24時間後は0.70に 6〜12時間後で減少の傾向を示した.

\section{2) MAD $1.0 \mathrm{mg} / \mathrm{kg} /$ day 7 日間連続投与}

第 8 表に示す如く，去勢群においては前值 1.0 に比し 3 日目では $0.19 ， 7$ 日目では0.20と減少の傾向を示 した，甲剔去勢群では前值1.0に比し 3 日目では0.94，7日目では0.48と僅かに減少しているが有意の変動

第 7 表 去勢犬に対する Methylandrostendiol 投与の影響 (MAD 単回投与)

\begin{tabular}{|c|c|c|c|c|c|c|}
\hline \multirow{2}{*}{ 処 置 } & \multirow{2}{*}{$\begin{array}{l}\text { MAD } \\
\text { 投与量 }\end{array}$} & \multirow{2}{*}{ 実験番号 } & \multicolumn{4}{|c|}{ 血漿 TSH 值 $\mathrm{mJSU} / \mathrm{ml}$} \\
\hline & & & 前 值 & 6 時間後 & 12 時間後 & 24 時間後 \\
\hline \multirow{3}{*}{ 去勢群 } & \multirow{3}{*}{$1.0 \mathrm{mg} / \mathrm{kg}$} & 1 & 0.123 & 0.058 & 0.111 & 0.155 \\
\hline & & 2 & 0.058 & 0.084 & 0.023 & 0.064 \\
\hline & & 3 & 0.066 & 0.032 & 0.045 & 0.070 \\
\hline \multirow{2}{*}{\multicolumn{3}{|c|}{$\begin{array}{l}\text { 平 均 } \\
\text { 増 加 率 }\end{array}$}} & 0.082 & 0.057 & 0.060 & 0.096 \\
\hline & & & 1.00 & 0.69 & 0.73 & 1.17 \\
\hline \multirow{3}{*}{$\begin{array}{l}\text { 甲剔- } \\
\text { 去勢群 }\end{array}$} & \multirow{3}{*}{$1.0 \mathrm{mg} / \mathrm{kg}$} & 4 & 0.912 & 0.363 & 0.575 & 2.400 \\
\hline & & 5 & 3.890 & 0.339 & 0.011 & 0.980 \\
\hline & & 6 & 1.070 & 0.501 & 0.022 & 1.120 \\
\hline & \multirow{2}{*}{\multicolumn{2}{|c|}{$\begin{array}{l}\text { 平 均 } \\
\text { 增 加 率 }\end{array}$}} & 1.957 & 0.401 & 0.203 & 1.366 \\
\hline & & & 1.00 & 0.25 & 0.10 & 0.70 \\
\hline \multirow{2}{*}{$\begin{array}{l}\text { 正常犬 } \\
\text { 甲剔犬 }\end{array}$} & \multirow{2}{*}{ 対 照 } & 7 & 0.217 & 0.202 & 0.186 & 0.284 \\
\hline & & 8 & 5.370 & 7.000 & 5.750 & 7.250 \\
\hline
\end{tabular}

第 8 表 去勢犬に対する Męhylandrostendiol 投与の影響 (MAD $1.0 \mathrm{mg} / \mathrm{kg} /$ day 7 日間連続投与)

\begin{tabular}{c|c|c|c|c}
\hline \multirow{2}{*}{ 処 置 } & \multirow{2}{*}{ 奉験 } & \multicolumn{3}{|c}{ 血漿 TSH 值 $\mathrm{mJSU} / \mathrm{ml}$} \\
\cline { 3 - 5 } & 番号 & 前 值 & 3 日目 & 7 日目 \\
\hline & 1 & 0.123 & 0.151 & 0.151 \\
去勢群 & 2 & 0.016 & 0.013 & 0.015 \\
+ & 3 & 0.054 & 0.002 & 0.006 \\
MAD & 4 & 0.059 & 0.001 & 0.001 \\
& 5 & 0.661 & 0.009 & 0.008 \\
\hline
\end{tabular}

\begin{tabular}{|c|c|c|c|c|}
\hline & 均 & \multirow{2}{*}{$\begin{array}{l}0.183 \\
1.00\end{array}$} & \multirow{2}{*}{$\begin{array}{l}0.035 \\
0.19\end{array}$} & \multirow{2}{*}{$\begin{array}{l}0.036 \\
0.20\end{array}$} \\
\hline 増 加 & 率 & & & \\
\hline \multirow{4}{*}{$\begin{array}{l}\text { 甲剔- } \\
\text { 去勢群 } \\
+十 \\
\text { MAD }\end{array}$} & 6 & 3.630 & 2.766 & 1.210 \\
\hline & 7 & 0.933 & 0.692 & 0.386 \\
\hline & 8 & 1.820 & 1.480 & 0.661 \\
\hline & 9 & 1.350 & 2.390 & 1.360 \\
\hline \multirow{2}{*}{\multicolumn{2}{|c|}{$\begin{array}{l}\text { 平 均 } \\
\text { 増 加 率 }\end{array}$}} & 1.944 & 1.840 & 0.904 \\
\hline & & 1.00 & 0.94 & 0.48 \\
\hline 正常犬 & 10 & 0.209 & 0.234 & - \\
\hline 甲剔犬 & $\left(\begin{array}{c}\left(x_{0} \text { 照 }\right. \\
11\end{array}\right.$ & 2.190 & 2.280 & 2.880 \\
\hline
\end{tabular}


とは認め難い，以上 MAD を去勢群並びに甲剔去 勢群没投与して血中 TSH 值の変動を観察したが, T.P.とは逆に僅かに減少の傾向を示すが如き印象を うけた，対照犬は有意の変動を示さなかつた。

（付）去勢並びに Testosterone propionate 投与 による血清 PBI の変動

術後 47 日を経過せる去勢犬 5 例に T.P. $1.0 \mathrm{mg} / \mathrm{kg}$ を投与し，12時間後に更にT.P. $1.0 \mathrm{mg} / \mathrm{kg}$ を投与 して，12時間後にその血清PBI を測定した。第 9 表 に示す如く去勢前值の平均を 1.0 として，去勢後の T.P. 投与前値並びに投与後の值の平均と較べるに, 去勢後47日目においては0.63と減少を示し，T.P. 投 与により 1.21 と増加を示して去術前值に復した.
第 9 表 去勢犬に拈けるT.P.投与による血清 PBI の変動

\begin{tabular}{|c|c|c|c|c|}
\hline \multirow{3}{*}{ 実験番昜 } & \multirow{3}{*}{$\begin{array}{l}\text { 去 勢 後 } \\
\text { 経過日数 }\end{array}$} & \multicolumn{3}{|c|}{ 血清 PBI 值 $r / \mathrm{ml}$} \\
\hline & & \multirow{2}{*}{ 去勢前 } & \multicolumn{2}{|c|}{ 去 勢 後 } \\
\hline & & & T.P.投与前 & T.P.投与後 \\
\hline 1 & 47 & 5.2 & 2.3 & 7.3 \\
\hline 2 & 47 & 6.0 & 4.3 & 6.9 \\
\hline 3 & 47 & 5.7 & 3.0 & 6.2 \\
\hline 4 & 47 & 5.1 & 4.2 & 5.8 \\
\hline 5 & 47 & 5.4 & 3.6 & 7.4 \\
\hline 平 均 & - & 5.5 & 3.5 & 6.7 \\
\hline 比 率 & - & 1.00 & 0.63 & 1.21 \\
\hline
\end{tabular}

\section{第 4 章 総括並びに考按}

男性ホルモンが下垂体甲状腺系に及ばす影響については，いとぐちに触れた如くその報告は少なく，その 作用機序についても定説がない，男性ホルモンが下垂体前葉の TSH 分泌に及ぼす影響を知ることは，その 下垂体甲状腺系に対する作用機序を解明するに必須のととであろう．しかるに今迄ての分野の研究の少なか つた理由は血中 TSH が微量なる為にその刻々の変動を捉えるととが出来なかつた為と考元られる，植田4), 柴田 ${ }^{5}$ その他の綜説に述べられている如く，TSH の測定法には甲状腺重量を示標とする方法，甲状腺滤胞 上皮の細胞高，濾胞上皮細胞に出現する Colloid 小滴数，濾胞上皮細胞の有絲核分裂の数等を示標とする 組織学的所見の変化に基づく方法，おたまじやくしの変態を示標とする方法，甲状腺の $\mathrm{P}^{31}$ の摂取，或いは $\mathrm{I}^{131}$ の摄取又は放出の度を示標とする方法等種々なる測定法か溌表されている。しかしてれ等の in vivo 亿 おける Bioassay は，比較的に大量の TSH を必要とする為に微量なる血中 TSH の測定が出来難く，又検 定に使用せる動物の固体差，飼育条件，季節等の問題があり測定条件の均一化が困難である。したがつて， 現在迄に発表された正常人の血中 TSH 量も大体の值が記されているにすぎない. Bakke and Lawrence ${ }^{6)}$ in vitroにおける新鮮な牛甲状腺薄片を用いて， I ${ }^{131} の$ Collecting mechanism を示標とせる方法により比 較的微量な TSH の定量法を発表したが，未だ血中 TSH の測定には触れていない.しかし in vitro 法で は in vivo における bioassay 亿較べて，測定せんとする TSH が生体内で稀釈破壊されるととなく，乙 れを目標藏器に直接作用せしめるととが出来, 且つ多数の資料を同一条件で同時に測定出来る利点がある. 教室の小倉 ${ }^{177)}$ はてれらの利点に着目して，Bake らの方法を改良発展せしめ，in vitro における新鮮な牛甲 状腺薄片の ${ }^{131}$ Release 法によつて始めて実用性のある血中 TSH 測定法を得た。乙の方法は血漿を10倍に 稀釈する為に，血漿中に存在する他の物質の影響を少なくする利点がある．乙の方法を実施する際には以下 の点に注意する必要がある。すすなわち，1）牛甲状腺は充分に選択し，甲状腺腫を疑わしむるものは總対に 避ける. 近年肉用牛に対して肥㭌の目的で抗甲状腺剂を使用する向もあり，小倉等》のいう Thyroid index 0.5 以下のものを使用する。 2) 牛の年令は $2 \sim 3$ 才のものが適当で 5 才以上のものは使用しない. 3) 雌牛 は甲状腺機能に変化が多いから必ず去勢雄牛を使用する，4）薄片を扱う際は常に一定のテクニックで迅速 に行ない，薄片に対する高温，乾燥は禁忌である．著者はての小倉の方法を用いて血中 TSH 値の測定を主 題とし，同時に血清 PBI の測定を併せ行なつて，男性ホルモンの下垂体甲状腺系における意義を明らかに せんと試みた，先ず雄犬について去勢による血中 TSH 值の変動を経時的に観察した．すなわち，正常大を 去勢するとその血中 TSH 值は術後 9 日以内に一時上昇するが，その後漸時減少の傾向を示し，第30〜60日 後頃に最低值を示し,それ以後は再びレベルを上げて術後 120 日前後において去勢值の約 $40 \%$ 迄恢復上㫒し固 
定している. 又あらかじめ甲状腺剔出術を行ない，術後 TSH レベルの固定せる雄犬について去勢を行なつ た. この場合は正常犬の場合と異なり, 血中 TSH 值は術後直ちに減少を示し，8１4日後に最低值に達し， その後辢時上昇恢復の傾向を示すが, 術後 100 日前後に至つてもなお術前値に較べて低值に止つているてと を認めた．正常犬において去勢術後認められた血中 TSH 值の一時的な上昇は，Crepax 吾か雄 rat を去勢し て10日以内に甲状腺が組織学的に機能充進像を示すてとを認め, 斉藤" は雄家兔を去勢して 1 週間後に甲状 腺重量の増加を認めた如く手術侵襲によるものと考えられ，教室の佐古田 ${ }^{3}$ の研究結果によく一致している. 甲剔犬においてての様な手術侵襲の影響が見られなかつたてとは, 甲剔犬が去勢術前においてその TSH レ ベルは既に高く，為に重なるTSH 分泌刺激機転に応じられなかつたのではないかと考光られる，又去勢後 減少した血中 TSH レベルが漸時上昇恢復するてとは，去勢に対して適応する生体反応とも考えられる。乙 の点山口 ${ }^{10)}$ も倠を去勢して 2 週後に甲状腺機能が低下し，後渐時恢復するてとを認めている．

去勢の甲状腺に及ぼす影響については従来より多くの研究がなされている. Anderson \& Kennedy ${ }^{11)}$ は成熟 rat で，Hatai ${ }^{12}$ は未成熟 rat で，Schulze and Turner ${ }^{13}$ は鵎で，Morris ${ }^{14)}$ に白色レグホンで夫々去勢による 甲状腺機能の低下を認めている。しかし，その機能低下を示す時期は報告により差があり，Anderson \& Kennedy ${ }^{11)}$ は成熟 rat で $3 \sim 8$ 週以後, Hatai ${ }^{12}$ は未成熟 rat で $3 \sim 5$ 月以後, $\mathrm{Crepax}^{8}$ は雄 rat で40〜90日 以後, Morris ${ }^{14)}$ は白色レグホンで57日以後, Breneman and Mason $\left.{ }^{15}\right)$ は 120 日以後, 斎藤 ${ }^{99}$ は雄家兔で 4 週以後 に夫々機能低下を来すと報している。乙れは動物の種属差, 或いは同種の動物でも成熟の程度や固体差によ り異なるのではないかと考えられる. 又井上 ${ }^{16)}$ は雄 rat において去勢による甲状腺機能の低下が42目以後に 起るとして，一方山口 ${ }^{10)}$ は雔 rat の去勢により同様の現象が14日以後におてるてとを報しているてとよりみ ると, 同種の動物においても性差がありそうである. 以上の去勢による甲状腺機能低下を認める説に対して, Choucke ${ }^{17)}$ はモルモットを去勢して甲状腺に組織学的な影響を認めず，Odel1 ${ }^{18)}$ は白色レグホンで甲状腺機能 は不変であるとし，Mercier-Parot ${ }^{19)}$ は幼若 rat を去勢して濾胞上皮細胞高は不変であつたと報じている. 又 Aron and Marescaux ${ }^{20)}$ はモルモットにおいて去勢により甲状腺の機能克進像を認めている。しかし他の多く の発表は去勢により甲状腺に於ては組織学的所見から，或いはI I ${ }^{131}$ をレレーサーとして用いたヨード代謝面 から機能低下を認め, Tuckmann-Puplessis and Mercier-Parot ${ }^{21}$ も後に成熟 rat において組織学的に機能低下 像を認めている，以上述べた如く，時期の相違はあつても，去勢動物は種類性差を問わず早晩甲状腺機能の 低下を来すものと考元れる。著者の実験にわいても去勢犬で PBI の低下を認めててれらの報告に一致す る結果を得ている，以上の如く，去勢動物の甲状腺機能をみた報告は処々にみられるが，去勢が下垂体前葉 の TSH 分泌に及ぼす影響について観察した報告はきわめて少なく, 僅に Turner and Cupps ${ }^{22) か ゙ ~ r a t ~ て ゙, ~}$ Bates ${ }^{23)}$ 等が牛で去勢により下垂体の TSH 量の減少を推論しているのみで，乙の点血中 TSH 值を直接測定 した著者の成績は意義深いものといえよう。

下垂体前葉における TSH 産生母体については, 従来 $\alpha$ 細胞， $\beta$ 細胞，或いは chromophobe 細胞説と種 々論議されてきた。近年組織化学的な方法による細胞分析が進歩し, Purves and Griesbach ${ }^{24}$ は PAS 染色や Paraldehyde fuchsin 染色により下垂体前葉の塩基好性細胞を gonadotroph と thyrotroph とに分ち, Gomori 陽性顆粒を有する thyrotroph を TSH の分䟤細胞とみなした，ての説は同様の方法をもつて $\beta$ 細 胞を産生源とする $\mathrm{Halmi}^{225)}$ の説とよく一致しており現在ての説が有力である. 他方 Holweg and Dohrn ${ }^{26)}$, Kushinsky ${ }^{27}$ 以来下垂体前葉と性腺の間には teed back の相関々係があり，去勢動物においては下垂体前葉 の gonadotropin の分泌充進をきたすてとが認められている. 同様な相関は甲状腺と下垂体前葉との間に も認められ，Salter ${ }^{28}$ は thyroxine が視床下部中枢に㗢いて下垂体前葉の TSH 分泌を抑制し, Hoskins ${ }^{29)}$ は血中 thyroxine 濃度が上昇すれば TSH 分泌は抑制されるとしている。 又 Severinghaus ${ }^{30}$ によれば， thyroxine 投与が下垂体前葉の塩基好性細胞の退萎を招き，甲状腺剔出が腺葉の塩基好性細胞の過形成ない

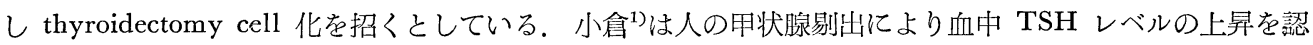
め又甲剔犬の血中 TSH の規則的な昇降変化を認めた。著者の犬における甲剔の成績もよくてれに一致して いる．乙の様に甲状腺の亜全剔ないし全剔出を行なつて下垂体前葉の TSH 分泌充進をきたした場合，換言 
すれば所謂 thyrotroph の機能过進をきたした場合に，thyrotroph と相接して存在している gonadotroph

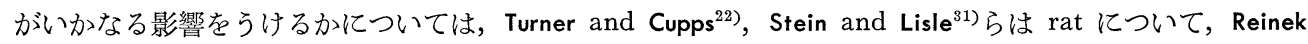
${ }^{32)}$ は雄山羊について，辻田 ${ }^{33}$ は家鬼について実験を行ない，それぞれ gonadotropin の分泌低下を認めてい る.すなわち, thyrotroph の機能充進は相対的に, gonadotroph の機能低下を招来せしめるものと思われ る。著者は雄犬の去勢により血中 TSH 值の低下を認めたが，てれは以上述べた過程の逆の関係を示すもの と考えられる。すなおち，Nelson and Hickman ${ }^{34)}$ が甲剔による thyroidectomy cell の出現は，去勢による castration cell の形成により抑制をうけるてとを報しているてとよりみても，去勢による gonadotroph の 機能克進が相対的に thyrotroph の機能低下を招いたのではないかと推察される. 更に著者は去勢により血 清 PBI の減少を認めたてと及び甲状腺剔出を行なつて甲状腺から下垂体前葉への feed back の影響を無く した場合においても，去勢により血中 TSH 值の減少を認めたてとはての推論を裏づけるものとしてよい． すなわち，去勢動物において甲状腺機能の低下を来す原因には，下垂体前葉の TSH 分泌低下が重要なる役 割を演じているものと考えられる。

著者は又，去勢犬並びに甲剔去勢犬に男性ホルモンとして Testosterone propionate 並びに Methylandrostendiol を投与量並びに投与方法を種々変えて与光，その血中 TSH 値に及ぼす影響を観察した。 その結 果, Test. hept. $5.0 \mathrm{mg} / \mathrm{kg}$ 単回投与の 3 日目における血中 TSH 值の上昇が最も著明で, 以下 T.P. $1.0 \mathrm{mg} /$ $\mathrm{kg} /$ day 3 日間連続投与, T.P. $0.5 \mathrm{mg} / \mathrm{kg} /$ day 3 日間連続投与, T.P. $1.0 \mathrm{mg} / \mathrm{kg}$ 単回投与, $5.0 \mathrm{mg} / \mathrm{kg}$ 単回 投与, $0.1 \mathrm{mg} / \mathrm{kg}$ 単回投与の順に効果を現し，去勢犬における T.P. の効果は甲剔去勢犬におけるよりも著 明であるととを認めた．MAD 投与の去勢犬及び甲剔去勢犬の血中 TSH 值に及ぼす影響はきわすて少なく， 不変であるか，或いは僅かに低下せしめるかの如き程度に止つた。

男性ホルモンの男状腺に及ぼす影響についての報告は, 研究者により必ずしも一致していない. Lewis and $\mathrm{McCullagh}^{35}$ ), Nathanson ${ }^{36}$ は未成熟の rat に T.P. をあたえ, 高折 ${ }^{37}$ は成熟 rat に T.P. を長期間投与し て何れも組織学的に機能充進像を認め，Money ${ }^{38)}$ 等は低ヨード食で飼育した rat そT.P. を投与して甲状腺 $I^{131}$ 摄取率の増加を認めている. 又 Burris ${ }^{39}$ 等は若い牡牛に T.P. を投与して Thyroxine の分泌促進を推察 し，Castellani ${ }^{40}$ は成熟モルモットに T.P. を投与し，0.1 mg 15日間投与群に甲状腺の機能充進像を認めてい る.乙れ等の成績に反し，Leathem ${ }^{41}$ は T.P.により甲状腺重量は不変とし，Crepax ${ }^{42}$ は T.P. を正常又は去 勢 rat に投与して組織学的に影響なしとし, Aron and Marescaux ${ }^{20)}$ も正常又は去勢モルモットにT.P. を投 与して甲状腺機能への影響を認めず，Odell ${ }^{18)}$ は白色レグホンの Thyroxine 分泌速度に T.P.は無関係であ つたとしている. 又逆に Gassner ${ }^{43)}$ 等は rat に T.P.を投与して甲状腺 $\mathrm{I}^{131}$ 摄取率の低下を認め，井上 ${ }^{16)}$ は 去勢 rat にT.P. を投与して甲状腺機能は軽度抑利されるか又は不変であつたと報じている，以上の如く雄 性動物に対する T.P. の影響は各報告者において差異があり，動物の糖類並びに実験条件により相違を来た したものと考えるよう他はない．山本 ${ }^{44}$ は男性ホルモンの少量は甲状腺機能を充進し，大量又は長期間投与 は抑制すると論じている，著者は雄去勢犬に T.P. を投与して血中 TSH 值の上昇を認めたが， $1.0 \mathrm{mg} / \mathrm{kg} /$ day の量が最も勅果的であつたととから，乙の量が血中 TSH 值の上昇に有効に作用する量ではないかと 考光る.

一般に性ホルモンが下垂体を介して甲状腺に作用するのか，或は直接甲状腺に作用するのかについては論 議の多い間題である. Turner and Cupps ${ }^{22)}$, Brown-Grant ${ }^{45)}$, Leblond et al. ${ }^{46)}$, Nelson and Hickman ${ }^{34)}$, Gassner et al. 等は下垂体仲介説を支持し, Braver ${ }^{47}$, Feldman ${ }^{48) 49}$, Money et al. ${ }^{38)}$ 等は甲状腺への直接作 用を認め, 高折 ${ }^{37}$ は estrogen は下垂体を介し, androgen は直接甲状腺に作用すると報している。しかし てれ等諸家の説は直接血中 TSH 值を測定した根拠亿基づくものでなく，いわば間接的な実験成績によつた ものである．著者は雄去勢犬並びに雄甲剔去勢犬に T.P. を投与して何れにも血中 TSH の増加を証し, 且つ 去勢犬においては同時に血清 PBI の增加を認めた。乙のととよりみると，T.P.は下垂体を介して甲状腺に 作用するものと考元られる.MAD については, 高折 ${ }^{37)}$ は下垂体剔出 rat にてれを投与して対照の垂剔 rat よりも甲状腺重量が大であり，組織の萎縮像も軽く且つ核分裂像を認めたてとから，甲状腺への直接作用を 
認めている，著者は MAD を雄去勢犬並びに雄甲剔去勢犬に投与して，血中 TSH 值が不変又は軽動の減 少をみたてとから，MAD は T.P. と異なり下垂体甲状腺系に対してむしろ抑制的に作用するのではないか と考光る。

\section{第 5 章 結 語}

1）雄成犬では去勢により，血中值 TSH は術後 9 日以内に一時上昇し，次で減少して 30 ６0日後におい て最低值を示し, 後漸時増加恢復するが術後120日前後においても尚前值に較べて低值を示した。

2）術後一定の経過を経た既に可成り高い血中 TSH 值を示している雄甲状腺剔出犬に去勢を行なうと, 正常大の如き手術侵襲による血中 TSH 值の上昇は認められず，血中 TSH 值は去勢後直ちに減少して8〜 10日目において最低値を示し，その後輈時増加恢復するも術後 100 日前後においても尚去勢前值に較へて低 值止つた.

3） T.P. は雄去勢犬の血中 TSH 值を增加せしめ, 同時に血清 PBI も増加せしめた. その血中 TSH 值 上昇作用は Testosterone heptanoate $5.0 \mathrm{mg} / \mathrm{kg}$ 単回投与, T.P. $1.0 \mathrm{mg} / \mathrm{kg} / \mathrm{day}$ 或は $0.5 \mathrm{mg} / \mathrm{kg} / \mathrm{day} 3$ 日間 連続投与の如くに適当量の持続的投与の際に最も強く現われ，T.P. $1.0 \mathrm{mg} / \mathrm{kg} ， 5.0 \mathrm{mg} / \mathrm{kg}$ ，或は $0.1 \mathrm{mg} /$ $\mathrm{kg}$ 単回投与の順に作用の減弱するととを認めた。

4) T.P.に対する反応として一般に，去勢群では甲剔去勢群よりも血中 TSH 值上昇率が大であつた。 て れは甲剔犬の血中 TSH レベルが既に上界近く迄上昇しており, 反応程度の低下を伴うものと考学られる。

5）以上の去勢及び T.P. 投与による血中 TSH 值の低高は下垂体前葉の性腺刺激ホルモン及び TSH 産 生作用の結抗的態度から説明するてとが出来る。

6） MAD は雄去勢犬並びに雄甲剔去勢犬の血中 TSH 值を軽度減少せしめるか又は殆んど変化を与えな い. 即ち MAD はての点において非作用的であつた.

(文献後出)

\section{第 2 編 甲状腺との関係について}

目次

\section{いとぐち}

\section{第 1 章 実験方法}

第 1 節 Paper radiochromatography

第 2 節 甲状腺 $\mathbf{I}^{131}$ 摂取率

第 3 節 血清 $\mathrm{PBI}^{131}$ 転換率

第 4 節 血清 PBI

第 5 節 組織学的検索

第 2 章 TSH 投与の甲状腺に及ぼす影響

第 1 節 Paper radiochromatogram

第 2 節 甲状腺 $\mathrm{I}^{131}$ 摂取率

第 3 節 血清 $\mathrm{PBI}^{131}$ 転換率

第 4 節 血清 PBI

第 5 節 組織学的所見

第 3 章 T.P. 投与の甲状腺に及ぼす影響
次

第 1 節 Paper radiochromatogram

第 2 節 甲状腺 $\mathrm{I}^{131}$ 提取率

第 3 節 血清 $\mathrm{PBI}^{131}$ 転換率

第 4 節 血清 PBI

第 5 節 組織学的所見

第4 章 MAD 投与の甲状腺に及ぼす影響

第 1 節 Paper radiochromatogram

第 2 節 甲状腺 $\mathrm{I}^{131}$ 摂取率

第 3 節 血清 $\mathrm{PBI}^{131}$ 転換率

第 4 節 血清 PBI

第 5 節 組織学的所見

第 5 章 総括並びに考按

第 6 章 結 語 


\section{いとぐち}

Kenedall ${ }^{50)}$ ，Harrington ${ }^{51}$ の古典的な研究により甲状腺組織内のヨードアミノ酸は Diiodotyrosine (DIT)， Thyroxine $\left(\mathrm{T}_{4}\right)$ のみとされ，30 年以上の永きに亘り $\mathrm{T}_{4}$ が唯一の甲状腺ホルモンとされていた. しかし近 年に至り放射性ヨードが tracer として甲状腺ホルモンの化学分野に導入され, 又 Chromatography, 殊に Paperchromatography による微量分析術の進歩，更に $I^{131}$ とPaperchromatography との組合せ等により甲 状腺ホルモンの化学が急速に進歩した. Monoiodotyrosine $(\mathrm{MIT})^{52)}$, Triiodothyronine $\left(\mathrm{T}_{3}\right)^{\left.53)^{54}\right)}$ 等が正 常な甲状腺に存在するととが確証されれのもその結果である. 殊に Gross and Pitt-Rivers ${ }^{53}$ や Roche ${ }^{54)}$ 等が 殆んど同時に発見した $\mathrm{T}_{3}$ は，乙れ迄唯一の甲状腺ホルモンとされていた $\mathrm{T}_{4}$ の 3 倍の強力な生理学的作 用を有するもので特筆すべき進歩といわねばならない，又 Hydovitz $\left.{ }^{55}\right)$ は正常及び機能九進時の甲状腺におい て TSH 投与が血清内の $\mathrm{T}_{3}, \mathrm{~T}_{4}$ を増加せしめることを Paper chromatography により証明し, 檜垣 ${ }^{56)}$ は単純 性濔漫性甲状腺腫の甲状腺組織内のヨード代謝を Paper radiochromatography により検討してヨード代謝 障碍の存在することを認め，小倉等 ${ }^{7}$ は in vitro において正常甲状腺及び甲状腺腫の腺葉薄片に $\mathrm{I}^{131}$ を負荷 せしめ Paper radiochromatography によるョード分析を行なつている. かくの如く Paperchromatography， 殊に $I^{131}$ を用いた Paper radiochromatography は現在甲状腺の化学的研究には甚だ重要な意義を有してい る，著者は第 1 編において，男性ホルモンが下垂体甲状腺系に及ぼす影響について，血中 TSH 值の変動を 主として観察を行なつたが，本編においては，男性ホルモンが TSH の目標蔵器である甲状腺の組織内ヨー

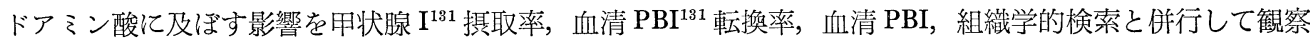
し，男性ホルモンの下垂体甲状腺系に及ぼす作用機序について総括的な考察を行なつた。

\section{第 1 章 実 験 方 法}

第 1 節 Paper radiochromatography

実験犬は第 1 編におけると同一の条件のものを用いた。実験大の甲状腺は Isozol 静脈内麻酔下に左右同 時に剔出した. 右葉のほぼ中央部を矩形に初り出し，その $200 \mathrm{mg}$ を $\mathrm{PH} 8.4$ 亿調製せる $\mathrm{NH}_{4} \mathrm{OH}-\mathrm{NH}_{4} \mathrm{Cl}$ 緩衝液 $5 \mathrm{cc}$ を加えて 氷冷下に homogenize したのち, trypsin $10 \mathrm{mg}$, urea $100 \mathrm{mg}$ を加えて $38^{\circ} \mathrm{C}$ で72時間 incubate して加水分解した. 乙の加水分解液に n-Butanol 10cc 加えて 5 分間強く振盪し遠沈して上澄 をとる。乙の沈渣に $5 \mathrm{cc} の \mathrm{n}$-Butanol を加えて 同様の操作で更に 2 回抽出し各上澄を合せて $45^{\circ} \mathrm{C}$ 以の Water bath で減圧乾固する。乾固物を $0.5 \mathrm{cc} の \mathrm{n}$-Butanol で溶解し濾紙の原線上に棒状に塗布する. 濾紙 は短冊型の東洋濾紙 No. 50 を用い，その下端より $5 \mathrm{~cm}$ の所に原紙をおく. 次で濾紙の下端より $30 \mathrm{~cm} の$ 所ま で n-Butanol-酢酸- $\mathrm{H}_{2} \mathrm{O}(40: 10: 50)$ 展開する。展開完了後乾燥して strip counting により各ヨードア ミノ酸の分析を行なつた. strip counting に際しては濾紙を原線より展開上界まで25等分し, 各切片につい て Geiger-Müller counter（神戸工業製）を用いて $\beta$ 線測定を行ない，Paperchromatogram を作製した。 各分劃はそれぞれの標準品を用いて同様の操作で展開し，Ninhydrin で発色せしめそのRfより検定を行な つた。なお甲状腺組織内ヨードアミノ酸としては，Monoiodohistidine (MIH)，Diiodohistidine (DIH) も挙げられるが，乙れらについては標準品が得られず，為に同定を行ない得なかつた．鈴木苂によれば， n-Butanol-酢酸- $\mathrm{H}_{2} \mathrm{O}\left(10^{\circ} \mathrm{C}\right)$ 展開によるヨードアミノ酸の Rf は $\mathrm{MIH}(0.12), \mathrm{I}^{-}(0.21), \mathrm{DIH}(0.40)$, MIT (0.43), DIT (0.59), $\mathrm{T}_{2}(0.80), \mathrm{T}_{3}(0.82), \mathrm{T}_{4}(0.86)$ としている. 著者は実技上 MIT と DIT, $\mathrm{T}_{3}$ と $\mathrm{T}_{4}$ の分離が必ずしも常には充分でなかつた為に, strip の原線より数えて第 7 第 9 初片を $\mathrm{I}^{-}$, 第 12 〜第17初片を $\mathrm{MIT}+\mathrm{DIT}$, 第 20 第 25 初片を $\mathrm{T}_{3}+\mathrm{T}_{4}$ の分劃として, 各分劃の Count 数の全数 Count 対する比を百分率で示した。

\section{第 2 節 甲状腺 $\mathbf{I}^{131}$ 㩒取率}

Leblond and Gross ${ }^{58)}$, Soliman and Reineke ${ }^{59}$ の方法により, 甲状腺の左葉を $2 \mathrm{~N} . \mathrm{NaOH}$ で加熱溶解後そ の1.0ccを乾燥して Geiger-Muller Counter で計数し，全葉の計数值に換算しててれを $\mathrm{Na} \mathrm{I}^{131}$ 投与量に対 
する百分率を以て甲状腺 $\mathrm{I}^{131}$ 撕取率とした。

\section{第 3 節 血清 $\mathrm{PBI}^{131}$ 転換率}

頸静脈より得た血液の血清 $0.5 \mathrm{cck} 2 \mathrm{~N} . \mathrm{NaOH} 1.0 \mathrm{cc}$ を加え加熱溶解し, その $1.0 \mathrm{cc}$ の計数值を血清全 $\mathrm{I}^{131}$ 計数值とした．別に血清 $0.5 \mathrm{cc}$ を Somogyi $\left.{ }^{60}\right)$ の変法 $\left.{ }^{61}\right)$ とり除蛋白洗條後の沈渣を $2 \mathrm{~N}$. NaOH で全量 を $1.5 \mathrm{cc}$ となし, 加熱溶解後その $1.0 \mathrm{cc}$ の計数值を以て血清有機 $\mathrm{I}^{131}$ 計数值となした.

\section{第 4 節 血清 PBI}

$$
\text { 血清 } \mathrm{PBI}^{131} \text { 転換率 }=\frac{\text { 血清有機 } \mathrm{I}^{131} \text { 計数値 }}{\text { 血清全 } \mathrm{I}^{131} \text { 計数值 }} \cdot 100
$$

ての測定は Barker'のアルカリ灰化法によつて行なつた。

\section{第 5 節 組織学的検索}

剔出甲状腺の右葉の一部をBouin 氏液で固定し，Hematoxylin-Eosin 染色を施した。組織像による機能 判定は入汇 ${ }^{62)}$ の分類によつた.

\section{第 2 章 TSH 投与の甲状腺に及ぼす影響}

第 1 節 Paperradiochromatogram（附図 1，I，II）

正常犬並びに去勢犬の各 2 例に TSH (Schering 社 Pretiron) を $10 \mathrm{JSU} / \mathrm{kg}$ 投与し， 6 時間後に再び TSH $10 \mathrm{JSU} / \mathrm{kg}$ 並びに Na I ${ }^{131} 100 \mu \mathrm{c}$ を筋注し，12 時間後に Isozol 静脈内麻醉下に左右両葉の甲状腺を同 時に剔出して測定に供した。第10表は TSH 及び次に述べる T.P. 並び MAD にの投与例における Paperradiochromatography, 甲状腺 ${ }^{131}$ 掑取率，血清 $\mathrm{PBI}^{131}$ 転換率，並びに血清 PBI の成績の平均値を一括して 示したものである．対照には正常犬及び去勢犬の各 2 例を生理食塩水及び $\mathrm{Na} \mathrm{I}^{131}$ で同様に 処置を行なつた ものを用いた。

第10表 TSH 並びに T.P., MAD 投与の甲状腺機能に及ぼす影響

\begin{tabular}{|c|c|c|c|c|c|c|c|c|c|}
\hline \multirow[b]{2}{*}{ 実 験 例 } & \multirow[b]{2}{*}{ 例数 } & \multicolumn{4}{|c|}{ 甲状腺組織内ヨード分布率（\%) } & \multirow{2}{*}{$\begin{array}{c}\text { 甲状腺 } \\
\text { I }{ }^{131} \\
\text { 摂取率 }\end{array}$} & \multirow{2}{*}{$\begin{array}{l}\text { 血 清 } \\
\mathrm{PBI}^{131} \\
\text { 転換率 }\end{array}$} & \multicolumn{2}{|c|}{ 血清 PBI $(r / \mathrm{ml})$} \\
\hline & & $I^{-}$ & $\mathrm{MIT}+\mathrm{DIT}$ & $\mathrm{T}_{3}+\mathrm{T}_{4}$ & $\frac{\mathrm{T}_{3}+\mathrm{T}_{4}}{\mathrm{MIT}+\mathrm{DIT}}$ & & & 前 & 後 \\
\hline 常 & 2 & 5.2 & 67.2 & 18.9 & 0.28 & 2.9 & 4.4 & 5.5 & 5.5 \\
\hline 正 常+TSH & 2 & 5.5 & 62.8 & 29.4 & 0.47 & 3.1 & 28.1 & 5.7 & 6.9 \\
\hline 去 & 2 & 5.8 & 66.0 & 20.1 & 0.30 & 2.6 & 3.0 & 5.5 & 5.4 \\
\hline 去 勢+ $\mathrm{TSH}$ & 2 & 4.2 & 57.9 & 31.4 & 0.54 & 4.0 & 35.9 & 5.4 & 8.2 \\
\hline 去 勢+T.P. & 2 & 5.9 & 60.2 & 30.1 & 0.50 & 3.4 & 27.7 & 5.6 & 6.8 \\
\hline 去 勢+MAD & 2 & 5.7 & 70.6 & 18.5 & 0.26 & 2.0 & 4.0 & 5.4 & 5.0 \\
\hline
\end{tabular}

$\mathrm{TSH}$ を投与せる正常犬は，I一の分劃の百分率は $5.2 \% ， \mathrm{MIT}+\mathrm{DIT}$ の分劃は $62.8 \% ， \mathrm{~T}_{2}+\mathrm{T}_{4}$ は29.4\%， $\mathrm{TSH}$ を投与せる去勢犬では，I-が4.2\%， MIT + DIT は $57.9 \% ， \mathrm{~T}_{3}+\mathrm{T}_{4}$ は $31.4 \%$ となつている。すなわ ち，TSH を投与せる例においては，対照に較べて I-の分劃には有意の変化が無く，MIT+DIT は減少し， $\mathrm{T}_{3}+\mathrm{T}_{4}$ は增加を示している. 従つて $\mathrm{T}_{3}+\mathrm{T}_{4} / \mathrm{MIT}+\mathrm{DIT}$ の比は $\mathrm{TSH}$ 投与により増大するととを認めた. 換言すれば TSH は甲状腺組織内において，MIT，DIT，から $\mathrm{T}_{3} ， \mathrm{~T}_{4}$ への移行を促進せしめるが如き作用 を有することを認めた。

第 2 節 甲状腺 $\mathbf{I}^{131}$ 摂取率

TSH 投与例に軽い上昇の傾向を認めた.

第 3 節 血清 $\mathrm{PBI}^{131}$ 転換率

TSH 投与によりそれぞれの対照に比して，正常犬では 6.4 倍去勢犬では 12 倍と著明に増加することを認 第37巻 第 6 号 
めた。

\section{第 4 節 血清 PBI}

$\mathrm{TSH}$ 投与前及び TSH を投 与して甲状腺を剔出する直前の 値を較べると，対照犬には殆ん ど変化か認められず，TSH を 投与した場合は正常犬で $1.2 \gamma$ $/ \mathrm{cc}$ ，去勢犬で $3.2 \gamma / \mathrm{cc}$ と何れも 增加の傾向を認めた。

\section{第 5 節 組織学的所見}

第11表は対照例及び TSH， T.P., MAD 投与例の甲状腺の 組織学的所見を一括して示した

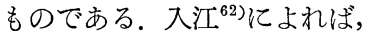
I 度及び II 度は所謂機能九進像 を表し，III度は正常像，IV度は 所謂機能低下像を表す，対照の 正常犬は殆んど正常像を示し， 去勢犬は一例か泟常像で他の一 例は殆んど正常像を示す. TSH を投与せる例においては何れも 明らかに機能充進像を認めた。

第 2 章 T.P.投与の甲 状腺に及ぼす 影響

第 1 節 Paper radiochromatogram (附図 1, III)

去勢大 2 例に T.P. $1.0 \mathrm{mg} / \mathrm{kg}$ を投与し， 6 時間後に更に T.P. $1.0 \mathrm{mg} / \mathrm{kg}$, 並びに Na I ${ }^{131} 100$ $\mu \mathrm{c}$ を投与し, 12 時間後に 前節 そ同様に甲状腺を剔出して測定 を行なつた。I-の分劃は $5.9 \%$ で対照に比して有意の差を認め ず，MIT + DIT は $60.2 \%$ と減 少し, $\mathrm{T}_{3}+\mathrm{T}_{4}$ は $30.1 \%$ と明ら かに増加している. 従つて $\mathrm{T}_{3}+$

$\mathrm{T}_{4} / \mathrm{MIT}+\mathrm{DIT}$ の比は T.P. 投与により增大するととを認めた。すすなわち T.P.は TSH と同様に甲状腺組 織内の MIT, DIT が $\mathrm{T}_{3}, \mathrm{~T}_{4}$ 亿移行する過程を促進する作用を有するととを認めた。

\section{第 2 節 甲状腺 $1^{131}$ 摂取率}

対照と TSH 投与例との間には有意の差を認めなかつた。

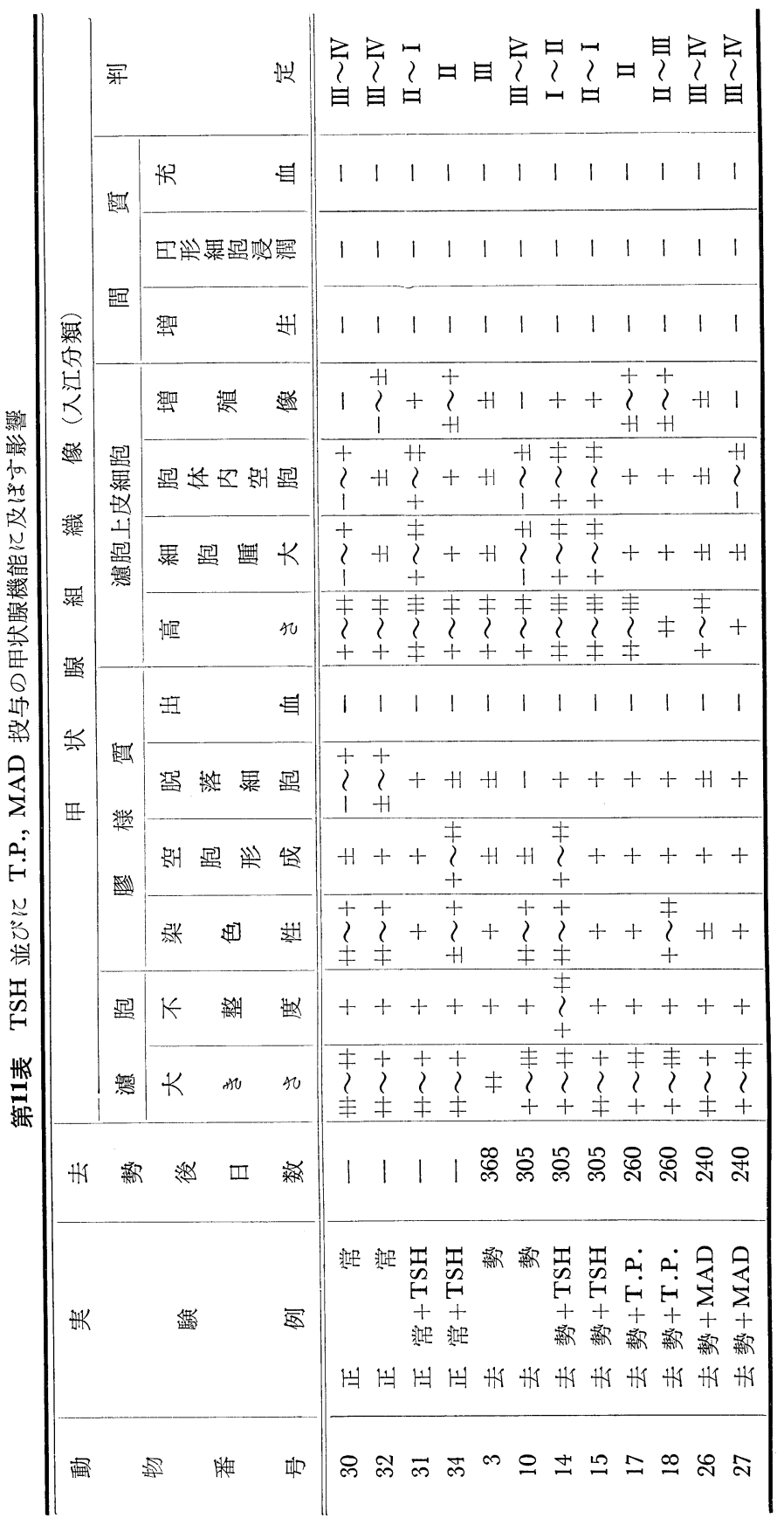




\section{第 3 節 血清 $\mathrm{PBI}^{131}$ 転換率}

T.P. 投与により, 対照の 6.3 倍と明らかに増加を示した。

\section{第4 節 血清 PBI}

T.P. 投与により，前值に較べて $1.2 \gamma / \mathrm{cc}$ の增加を認めた.

\section{第 5 節 組織学的所見}

T.P. 投与例では対照に較べて, 濾胞上皮細胞高の増大並びに増殖像を示し, 明らが機能充進像を認めた。

\section{第 4 章 MAD 投与の甲状腺に及ぼす影響}

第 1 節 Paper radiochromatogram (附図 1, IV)

前章と同様に，去勢犬 2 例に対して MAD $1.0 \mathrm{mg} / \mathrm{kg}$ を投与し， 6 時間後に更に MAD $1.0 \mathrm{mg} / \mathrm{kg}$ 及び $\mathrm{NaI}^{131} 100 \mu \mathrm{c}$ を投与して，12時間後に甲状腺を剔出して測定に供した。

I-の分劃は $5.7 \%$ で対照の $5.2 \%$ 亿較べて有意の差は認められなかつた. $\mathrm{MIT}+\mathrm{DIT}$ は70.6\%， $\mathrm{T}_{3}+\mathrm{T}_{4}$ は $18.5 \%$ で何れも対照に較べて明らかな差は無く，従つて $\mathrm{T}_{3}+\mathrm{T}_{4} / \mathrm{MIT}+\mathrm{DIT}$ の比には MAD 投与により有 意の傾向は認められなかつた。

第 2 節 甲状腺 $\mathbf{~}^{131}$ 摂取率

対照に較べて有意の差を認めなかつた。

第 3 節 血清 $\mathrm{PBI}^{131}$ 転換率

対照に較べて明らかな差は認めなかつた。

\section{第 4 節 血清 PBI}

$\mathrm{MAD}$ 投与前值 $5.4 \gamma / \mathrm{cc}$ 亿較べて, 投与後值 $5.0 \gamma / \mathrm{cc}$ とやや減少を示した.

\section{第 5 節 組織学的所見}

2 例共僅かに機能低下像を示し, 対照に較べて MAD 投与による明らかな变化は認めなかつた。

\section{第 5 章 総括並びに考按}

さきに第 1 編に於て，男性ホルモンが下垂体甲状腺系に及ぼす影響を検討しその作用機序を究明した。す なわち，正常犬及び甲剔犬においても，去勢により血中TSH 值の減少を認め，更にてれらに Testosterone propionate を投与せる場合に血中 TSH 值の増加を認めた，又血清 PBI が，正常犬を去勢した場合に減少 し，Testosterone propionate を投与して増加することを認めた。 てれらのてとから，男性ホルモンの下垂 体甲状腺系に及ぼす影響に於ては下垂体先行説を推論した。本編ておいては，乙れ等の男性ホルモンが， TSH の target organ である甲状腺自体に如何なる影響を及ぼすかを，甲状腺組織内ヨードアミノ酸の分劃 を中心に，甲状腺 $\mathrm{I}^{131}$ 掑取率，血清 $\mathrm{PBI}^{131}$ 転換率，血清 PBI 及び組織所見の各観点から検討を行なつた。

まず去勢による甲状腺組織内のヨードアミノ酸分劃については，対照の正常犬に比して有意の変化を認め なかつた，乙の去勢大の 2 例は何れも去勢後363日，305日と長期間経過して血中 TSH 值の大体恢復したも ので, この点更に去勢後短期間の実験を行なう必要があると考えられる.

去勢犬の 2 例に Testosterone propionate を投与した場合では, 対照に比して甲状腺組織内の MIT, DIT の減少並びに $\mathrm{T}_{3}, \mathrm{~T}_{4}$ の増加, 従つてその $\mathrm{T}_{3}+\mathrm{T}_{4} / \mathrm{MIT}+\mathrm{DIT}$ 比の明らかな増加を認め. 同時に血清 $\mathrm{PBI}^{31}$ 転換率，血清 PBI 值及び組織像の所見も共に甲状腺機能克進の像を示した，又，去勢犬に TSH を投与した 場合の甲状㘀組織内ヨードアミノ酸分劃をみるに，去勢犬に Testosterone propionate を投与した所見にほ ぼ等しく, MIT, DIT の減少, $\mathrm{T}_{3}, \mathrm{~T}_{4}$ の増加, 従つて $\mathrm{T}_{3}+\mathrm{T}_{4} / \mathrm{MIT}+\mathrm{DIT}$ 比の増加, 血清 $\mathrm{PBI}^{131}$ 転換 率, 血清 PBI の増加及び組織学的所見共機能九進像を認めた. すなわち, 以上の結果より, T.P. を去勢犬 に投与した場合の甲状腺組織内のヨードアミノ酸の分劃像は，去勢犬に TSH を投与した場合の態度とよく 一致している.

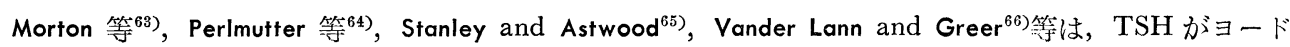


の有機化を高めることを報している，Randall and Albert ${ }^{67}$ ，Ghosh ${ }^{63)}$ 等は rat の脳下垂体を剔除するとヨー ドの有機化は正常の12〜30\%に低下し，Ghosh ${ }^{68}$ 等は TSH をてれに注射するる正常以上に恢復すると述へ， 更に Chaikoff and Taurog ${ }^{69}$ は DIT から $\mathrm{T}_{4}$ への過程が下剔体剔出によつて阻害され，ての際にヨードの有 機化は DIT の段階で停止するとし，Morton 等 ${ }^{70}$ は垂剔の際に DIT/ $\mathrm{T}_{4}$ の比が正常より増大するととを報 じている.

さきに，第 1 編において去勢犬に T.P. を投与せる場合，血中 TSH 值の增加は投与後 6 時間で既に認めら れたが，去勢犬に T.P. 投与後は時間を経て剔出せる大の甲状腺組織内のヨードアミノ酸の分劃像の動きは 略々 TSH 投与による変動のパターンと同傾向を示すてとから，T.P. 投与によつて先ず TSH の分泌が促進 され，その結果として甲状腺機能に変動を来したものと考えるのが至当であろう.

更に去勢犬 2 例飞 MAD を投与して同様の钼察を行なつた。 その結果，甲状腺組織内ヨードアミノ酸分 創，血清 $\mathrm{PBI}^{131}$ 転換率，血清 PBI，組織像共何れも対照の去勢犬に較べて有意の変化を認めなかつた。すな わち，乙の実験方法によつても MAD の甲状腺に及ぼす影響は直接，間接を間わず少ないものであると考 えられた。

\section{第 6 章 結 論}

甲性ホルモンの甲状腺に及ぼす影響を，甲状腺組織の Paper radiochromatography によるヨードアミ， 酸分劃像及び種々の甲状腺機能指標を用いて観察し次の如き結論をえた.

1）去勢後300〜360日を経過した犬の甲状腺組織内のヨードアミノ酸分割においては, 対照に較へてて有意 の変化を認めなかつた。

2) 去勢犬に Testosterone propionate を投与すると, 対照に較べて MIT, DIT の分劃が減少し, $\mathrm{T}_{3}$, $\mathrm{T}_{4}$ の分劃に增加が認められ, 従つて $\mathrm{T}_{3}+\mathrm{T}_{4} / \mathrm{MIT}+\mathrm{DIT}$ 比の増加を認めた.

3) 去勢犬に TSH を投与して, MIT, DIT の減少と, $\mathrm{T}_{3}, \mathrm{~T}_{4}$ の増加を認め, 従つて $\mathrm{T}_{3}+\mathrm{T}_{4} / \mathrm{MIT}+$ DIT 比の増加を認めた.

4) 従つて T.P.の甲状腺組織内ヨードアミノ酸分劃への影響は, TSH 投与時の所見とよく一致しており, T.P.が TSH の分泌を増加して甲状腺に作用する機構の存在を考光させる.

5） MAD の影響については一定の所見をえず，甲状腺への作用は少ないものと考えた。

6) 以上の Paper radiochromatography 分劃と同時江状腺 $\mathrm{I}^{131}$ 摄取率，血清転換率，血清 PBI，組織 学的所見等を同時に観察して，ほほ前述の実験結果に相等する結果を得た。すなわち，TSH 作用の増大を 予想される際には甲状腺機能元進像に相等する所見を, 又 MAD に就ては無作用又は軽度抑制傾向の存在 を認めた。

稿を終るにあたり終始御烈切な御指導を睗つた恩師过教授に愿く感謝致します。不実験に御協力頂いた教 室の小倉一博士, 弘重尚久学士並びに側面より御激励下さつた神戸市立玉津療養所長鴨志田正吾博士に心か ら感謝致します。.

(本論文の要旨は第 7 回並びに第 8 回日本内分泌学会西日本地方会の席上に於て発表した）

\section{文献}

1) 小倉一：日本内科学会雑誌，48：1045，1959. 2 2) Barker, S.B. and Humphrey, M.J. : J. Cl. Endocrinol., $10: 1136,1950$. 3) 佐古田雅弘 : 日本内分泌誌, 36:609, 1960. 4) 植田安雄, 他 : 木 ルモンと臨床，6:225，1958. 5) 柴田勝博：ホルモンと臨床, $4: 949,1956.6$ 6) Bakke, J.L. and N. Lawrence : Endocrinol., $58: 531,1956.7$ 7) 小倉一, 他 : 綜合医学, $17: 579,1960.48)$ Crepax, P. : Arch. Sci. Biol., 35 : 599. 1951. (Biol. Abst. : $28: 579,1954)$ 9) 斎藤隆: 日本内分 泌誌，6:355，1930. 10）山口彦司：神戸医大紀要，9:954，1957. 11 Andersen, D.H. and 


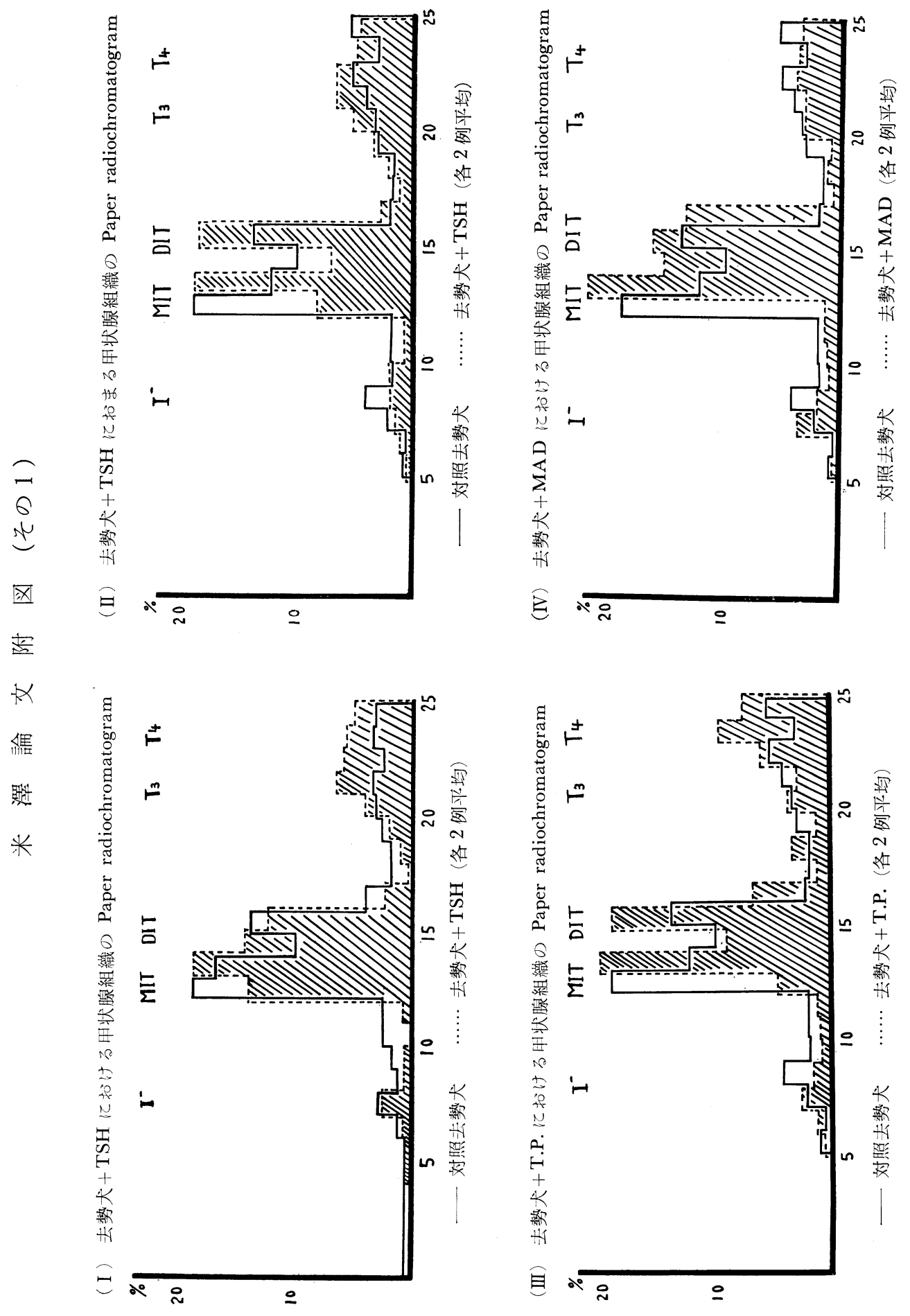




\section{米澤論文附図（その2）}

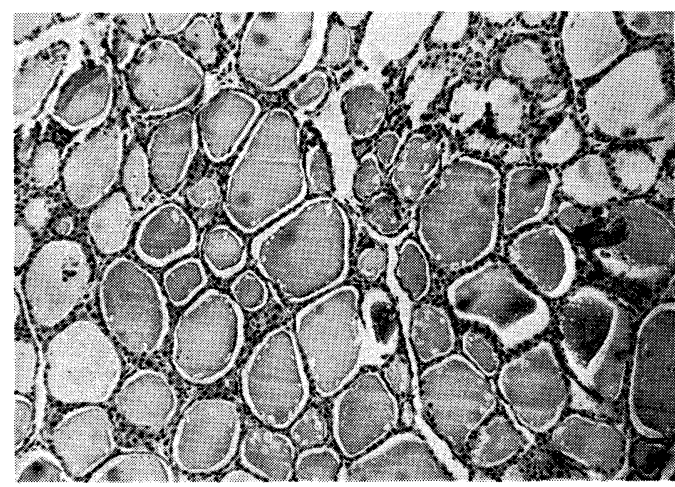

写真 1 正常無処置犬

(動物番号 30 )

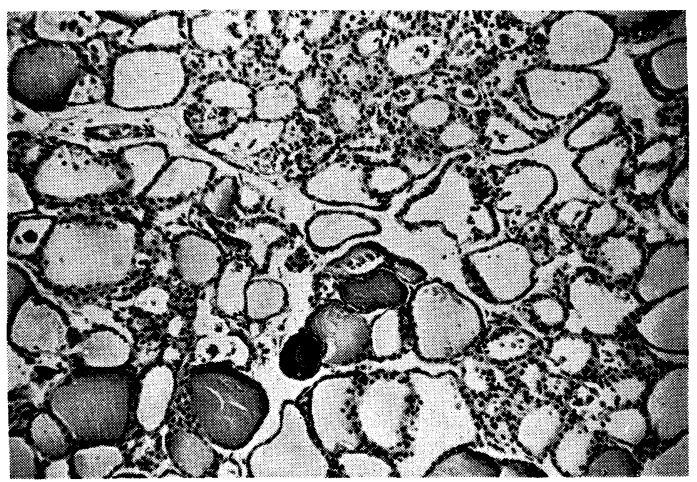

写真 3 去 勢 犬 動物番号 3 )

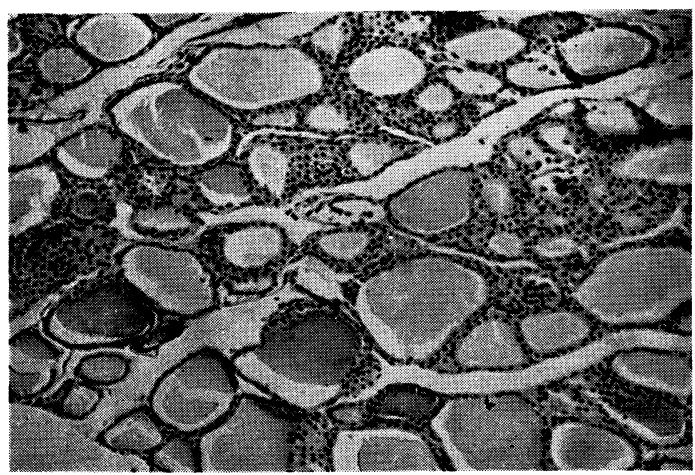

写真 5 去勢犬以 T.P. 投与 18時間後（動物番号17）

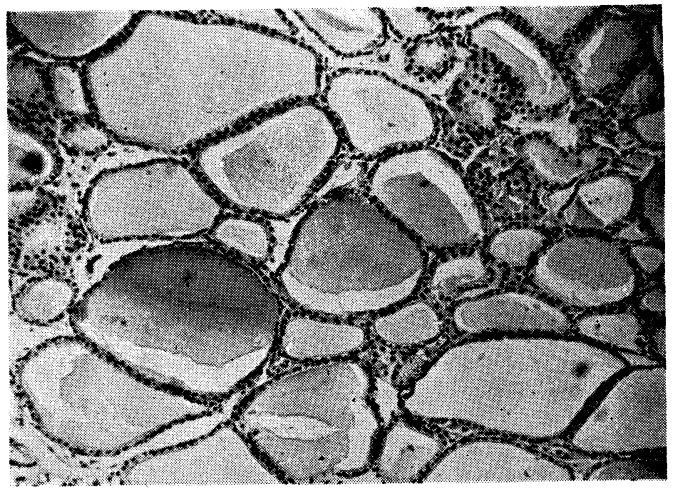

写真 2 正常犬に $\mathrm{TSH}$ 投与 18時間後（動物番号31）

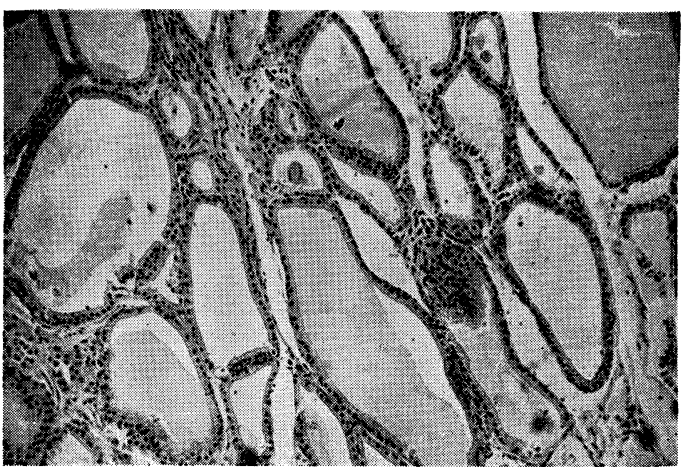

写真 4 去勢犬に TSH 投与 18時間後（動物番号14)

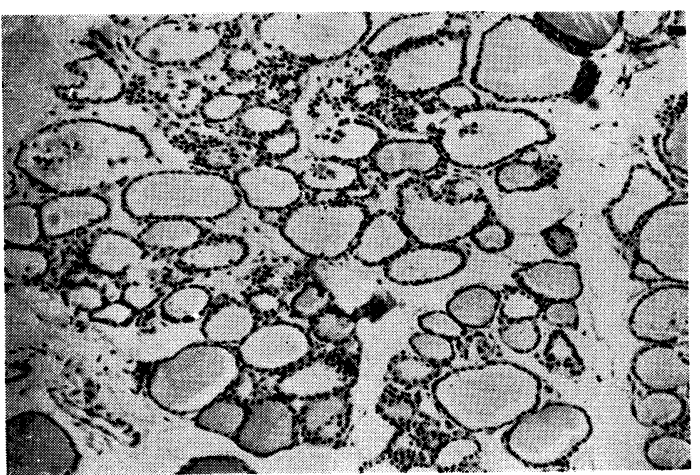

写真 6 去勢犬に MAD 投与 18時間後（動物番号26） 
H.S. Kennedy : J. Physiol., $79: 1,1933$.

12) Hatai, S. : J. Exp. Zool., $18: 1,1915$ (11より引用).

13) Schulze, A.B. and C.W. Turner : Univ. Missouri Agr. Exper. Sta. Res. Bull., 392, 1945. (44より引用). 14) Morris, D.M. : Endocrinol., $50: 277,1951$.

15) Breneman, W.R. and R.C. Mason : Endocrinol., $48: 752,1951$. 16) 井上康 : 日本内分泌誌，35:670，1959. 17) Chouke, K.S. : Endocrinol., $14: 12,1930$.

18) Odell, T.T. : Endocrinol., $51: 265,1952$. 19) Medcier-Parot, L. : Bull. Microscop. Appl., 2 : 117, 1952. (Biol. Abst., 27 : 1818, 1952). C.r. Soc. Biol., $146:$ 1388, 1952. (Excerpta, $7: 349$, 1953). 20) Aron, C. and J. Marescaux : Endocr., $14: 743$, 1953. (Chem. Abst., $48: 8362$, 1954).

21) Tuchmann-Duplessis, H. : Ann. Endocrinol., $26: 1042,1940$. 23) Bates, R. W. et al. : Amer. J. Physiol., $113: 259,1935$. 24) Purves, H.D. and W.E. Griesbach : Endocrinol., 49 : 224, 1951.

25) Halmi, N.S. : Endocrinol., $50: 140,1952 . \quad 26)$ Holweg, W. and M. Dohrn : Wien. Arch. int. Med., $21: 337,1931$. 27) Kuschinsky, G. : Arch. f. Exp. Path. Pharmakol., $162: 183,1941 . \quad 28)$ Salter, W.I. : Physiol. Rev., $20: 345,1940 . \quad 29)$ Hoskins, R.G. : J. Clin. Endocrinol., $9: 1429,1949$. 30) Severinghaus, A.E. : Allen's Sex and internal secreation. Baltimore, 1939. (46より引用). 31) Stein, K.F. and M. Lisle : Endocrinol., $30: 16,1942$. 32) Reineke, E.P. et al. : Endocrinol., 29 : 306, 1941. 辻田純二 : 日本内分泌誌，36:777，1960.

34) Nelson, W.O. and J. Hickman : Proc. Soc. Exp. Biol. Med., 36 : 828, 1937.

35) Lewis, L.A. and E.P. McCullagh : J. Clin. Endocrinol., 2: 502, 1942. 36) Nathanson, I.T. et al. : Proc. Soc. Exp. Biol. Med., $43: 737,1940$.

37) 高折忠太 : 日本内分泌 誌, $30: 543,1954 . \quad 38)$ Money, W.L. et al. : Endocrinol., $48: 682,1951 . \quad 39)$ Burris, M.J. et al. : Proc. Soc. Exp. Biol. Med., $84: 181,1953 . \quad 40)$ Castellani, L. : Arch. Maragliano Pat. Clin., $7: 79$, 1952. (Excerpta, $7: 12,1953)$. 41) Leathem, J. H. : Anat. Rec., $109: 318,1951$. 42) Crepax, P. : Boll. Soc. Ital. Biol. sper., $27: 1543$, 1951. (Ber. $156: 232,1953)$. 43) Gassner, F.X. et al. : Tr. Amer. A. Study. Goiter, P. 156, $1947 . \quad 44)$ 山本清: 内分泌機能の協関, P. 59, 1956. 45) Brown-Grant, K.: J. Physiol., $127: 390,1955 . \quad 46$ ) Leblond, C.P. et al.: Proc. Soc. Exp. Biol. Med., 51 : 159, $1942 . \quad 47)$ Brauner, F. et al. : Arch. internat. Pharmacodyn., 81 : 369, 1950. $\quad 48)$ Feldman, J.D. : Endocrinol., $58: 327,1956$. 49) Feldman, J.D. : Endocrinol., 59 : 289, 1956. 50) Kendall, E.C. : J. Biol. Ghem., $39: 125,1919$. 51) Harington, C.R. and S.S. Randall : Biochem. J., $23: 373,1929 . \quad$ 52) Fink, K. and R.M. Fink : Science, $108: 358,1948$. 53) Gross, J. and R. Pitt-Rivers : Lancet, $1: 437,1953 . \quad 54)$ Roche, J. et al. : Physiol. Review, 35 : 583, $1955 . \quad 55)$ Hydovitz, J.D. and W.L. Arons : Tr. Amer. Goiter. Assoc., P. 1332, $1957 . \quad 56)$ 檜垣修生 : 岡山医学会雑誌, $71: 1725,1959 . \quad 57)$ 鈴木光雄 : 内分泌子代謝, $1: 40,1958.58)$ Leblond, C.P. and J. Gross : Endocrinol., $43: 306,1948 . \quad 59)$ Soliman, F.A. and E.P. Reineke : Am. J. Physiol., $178: 89,1954 . \quad 60)$ Somogyi, M. : J. Biol. Chem., $86: 655,1930.61)$ 七条小 次郎, 他 : 日新医学, $39: 307,1952$. 62) 入江一彦 : 東北医誌, $55: 321,1957$.

63) Morton, M.E. et al. : Endocrinol., 30 : 495, 1942. 64) Perlmutter, M. et al. : J. Clin. Endocrinol., $12: 208$, 1952. 65) Stanley, M.M. and E.B. Astwood : Endocrinol., $44: 49,1949 . \quad 66)$ Vanderlann, W.P. and M.A. Greer : Endocrinol., $47: 36,1950 . \quad 67)$ Randall, R.V. and A. Albert : Endocrinol., $48: 327,1951 . \quad 68)$ Ghosh, B.N. et al. : Endocriuol., $48: 631,1951$.

69) Chaikoff, J.L. and A. Taurog : Ann. New York Acad. Sci., $50: 377,1949$. 70) Morton, M.E. et al. : J. Biol. Chem., $140: 602,1941$. 